\title{
Aalenian pulses of tectonic activity in the Iberian Basin, Spain
}

\author{
Alejandra García-Frank ${ }^{\mathrm{a}, *}$, Soledad Ureta ${ }^{\mathrm{a}}$, Ramón Mas ${ }^{\mathrm{b}}$ \\ a Departamento y UEI de Paleontología, Facultad CC Geológicas e Instituto de Geología Económica (UCM-CSIC), C/José Antonio Novais 2, 28040 Madrid, Spain \\ ${ }^{b}$ Departamento y UEI de Estratigrafia, Facultad CC Geológicas e Instituto de Geología Económica (UCM-CSIC), C/José Antonio Novais 2, 28040 Madrid, Spain
}

\section{Keywords:}

Condensed sequences

Tectonic controls

Aalenian

Iberian Basin

Spain

\begin{abstract}
A B S T R A C T
In the northwest Iberian Range the Aalenian to Bajocian interval is represented by condensed, as well as more expanded marine carbonate strata deposited in a shallow epicontinental-sea setting. Precise biochronological data (successive ammonites assemblages) from 29 measured sections, along with a bedby-bed facies analysis, allowed a detailed correlation between sections, the definition of a number of successive transgressive-regressive cycles and of two distinct sedimentation areas, as well as the compilation of isopach maps for short time intervals (duration of ammonites Zone/Subzone) and the assessment of sediment accumulation rates.

Differences in facies and thickness in the studied interval, and the sequential organization, reveal significant changes in the depositional environment. A tectonically-controlled compartmentalization of the sedimentation area is suggested by a detailed reconstruction of the accumulation history. An active extensional tectonic regime is supported by contemporaneous volcanic activity in the southeastern Iberian Basin.

A precise timing of the main tectonic pulses recorded in NW Iberian Basin for the Upper Toarcian-Lower Bajocian interval is presented, which may help to better resolve the stratigraphy in other W European during this time interval.
\end{abstract}

\section{Introduction}

Condensed units have frequently been cited in regional studies concerned with late-Early Jurassic to early-Middle Jurassic sedimentation in NW European, as well as peri-Tethyan basins, and they are generally considered to have been deposited during the regressive phase of a second-order stratigraphic cycle ( $\mathrm{N}$ and $\mathrm{W}$ Europe: e.g. de Graciansky et al., 1998; Hallam, 2001; Iberian Peninsula: O'Doguerty et al., 2000; Aurell et al., 2003; Gómez and Fernández-López, 2004; Gómez and Goy, 2005; Quesada et al., 2005). The record of the transgressive phase of this same cycle is typically constituted by deepening-upward hemipelagic limestone and marl alternations.

In the Iberian Basin (Fig. 1), condensed levels are characterized by the presence of hard grounds, oolitic ironstones and/or hiatuses of variable extent. In the Basque-Cantabrian Basin (Fig. 1), in the regressive hemicycle locally bioclastic limestones occur (e.g. Quesada et al., 2005), indicating shallowing of the carbonate ramp.

A significant sea-level fall at about the Early/Middle Jurassic boundary involved a marked change in the palaeogeography of the North Atlantic/W Tethyan realm. This period coincides with the early post-rift or late rifting stage in the Central Atlantic/W Tethys system, and with widespread basaltic volcanism, thermal doming and collapse in the North Sea region (Hallam and Sellwood, 1976; Ziegler, 1990; Cope et al., 1992; Underhill and Partington, 1993;

\footnotetext{
* Corresponding author. Fax: +34 913944849.

E-mail address: agfrank@geo.ucm.es (A. García-Frank).
}

Hesselbo and Jenkyns, 1998; Ford and Golonka, 2003; Golonka, 2004, 2007; etc.).

Consistent with this palaeogeographic scenario, the Early and Middle Jurassic record of the Iberian Basin (Figs. 1 and 2) shows evidence of synsedimentary extensional tectonic activity. A tectonic control on sedimentation during this time has already been inferred in a number of previous studies (Iberian Range: Ureta, 1985; FernándezLópez and Gómez, 1990; Goy and Ureta, 1990; Gómez and Goy, 2005; García-Frank et al., 2006b; Gómez and Fernández-López, 2006; García-Frank, 2007; Basque-Cantabrian Basin: e.g. Fernández-López et al., 1988; Betic Cordillera: e.g. Sandoval et al., 2002). However, in none of these studies neither on the detailed basin geometry nor on the precise timing of faulting has data been provided.

In the SE sector of the Iberian Basin the early Toarcian to early Bajocian time span was moreover characterized by multiple episodes of alkaline volcanism (see Fig. 2B), recorded mainly by volcanoclastic deposits and, subordinately, basaltic sills (Gautier and Odin, 1983; Fernández-López et al., 1985; Lago et al., 2004 and references therein). Early to Middle Jurassic magmatic activity has also been reported from the Algarve Basin (SW Iberian margin; Pinheiro et al., 1996 and references therein). In the Betic External Zones (Median Subbetic), sub-alkaline magmatic activity has been documented, with activity peaking in the Middle Jurassic (e.g. Martín-Algarra et al., 2004).

This study centres on the latest Early to early-Middle Jurassic (late Toarcian to early Bajocian) sedimentary record in the NW sector of the Iberian Range (Figs. 2 and 3). Compared to other Jurassic stages, in the Iberian Range Aalenian deposits(essentially limestones and marls) are 


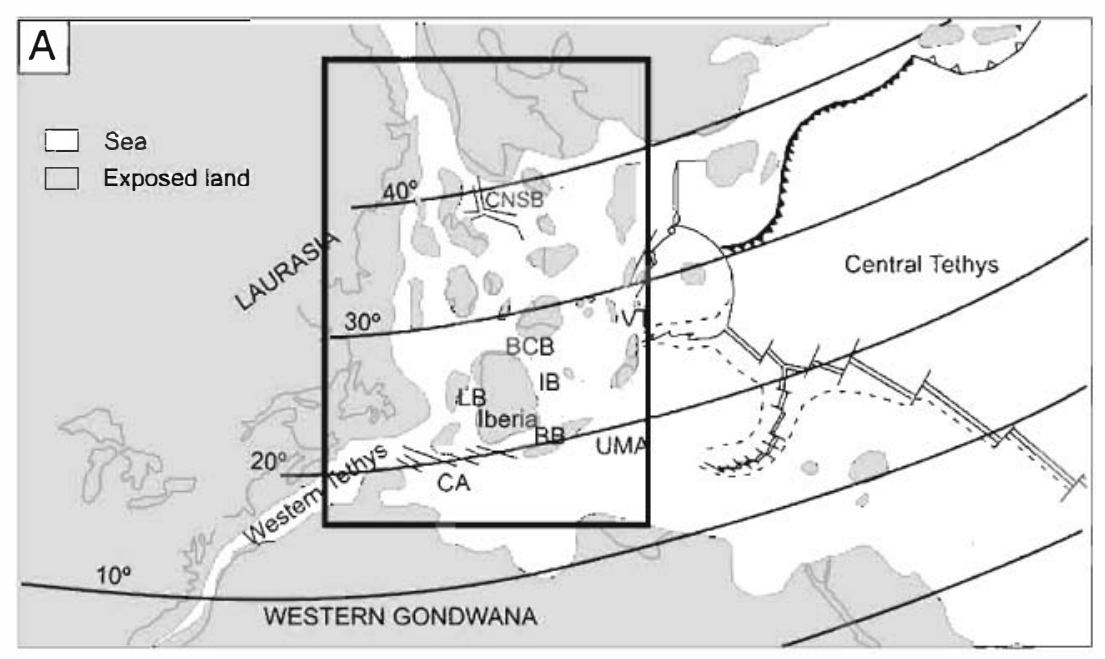

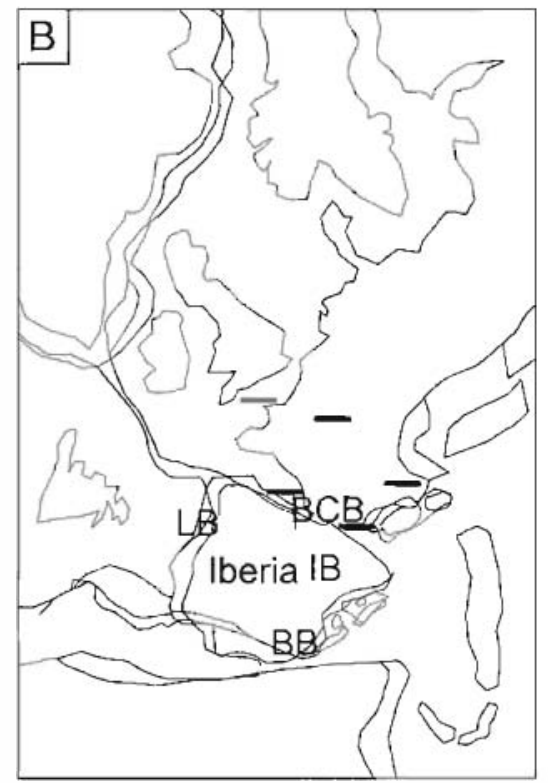

203-179 Ma

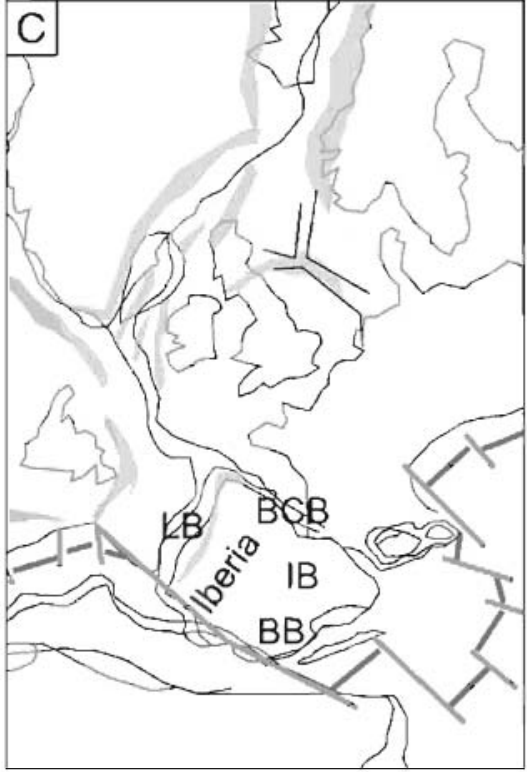

179-166 Ma

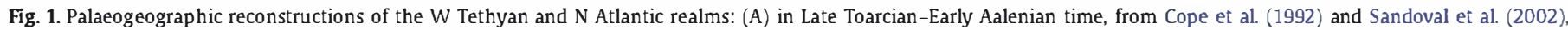

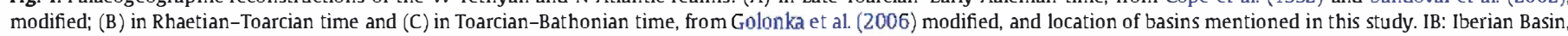

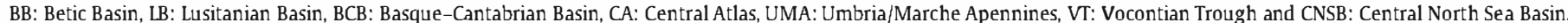

in general remarkably reduced in thickness and the constituent sequences frequently condensed (Üreta, 1985; Goy and Ureta, 1990; García-Frank et al., 2006b). A previous detailed stratigraphic and palaeontological study in the NW Iberian Range (Garcia-Frank, 2007) revealed that synsedimentary tectonics constituted a major control on facies and thickness distribution.

The present study includes refined stratigraphic correlations based on additional biochronological data (ammonites), a revised sequential subdivison, as well as isopach maps for each of the defined sequences, illustrating spatial and temporal variations of sediment accumulation.

The results obtained allow to assess the relative impact of eustasy and local tectonics on basin stratigraphy and sequential organization, and a comparison/correlation with the evolution observed in other European sedimentary basins.

\section{Geological setting}

The Iberian Range is a NW-SE trending intracontinental Alpine fold-and-thrust belt, about $600 \mathrm{~km}$ long, that comprises both
Variscan basement and the Mesozoic cover and shows a double vergence (Mas et al., 2003; Guimerá et al., 2004). The study area is located in the northwestern part of the Iberian Range (Fig. 2A). The range developed through tectonic inversion, during the Palaeogene and Miocene p.p., of the Mesozoic Iberian Rift System/Iberian Basin (e.g. Salas et al., 2001).

Since the end of the Paleozoic, the Iberian Plate has been affected by two major rifting events (e.g. Salas et al., 2001; Guimerá et al., 2004): the first is generally considered to span the Late PermianTriassic interval and to be followed by a phase of relative tectonic quiescence (post-rift thermal subsidence) extending to the end of the Middle Jurassic (Oxfordian). The second rifting event started by the beginning of Late Jurassic time and lasted until the late-Early Cretaceous (late Albian), and its corresponding post-rift stage spanned the Late Cretaceous-Palaeocene p.p. time interval.

Different chronologies have been reported from other Mesozoic basins of Iberia: According to Pinheiro et al. (1996), three rifting phases, Hettangian, late Oxfordian/early Kimmeridgian, Valanginian/ Hauterivian-Aptian in age, have affected the western Iberian margin. The S-Portuguese Mesozoic Algarve Basin is considered to have 


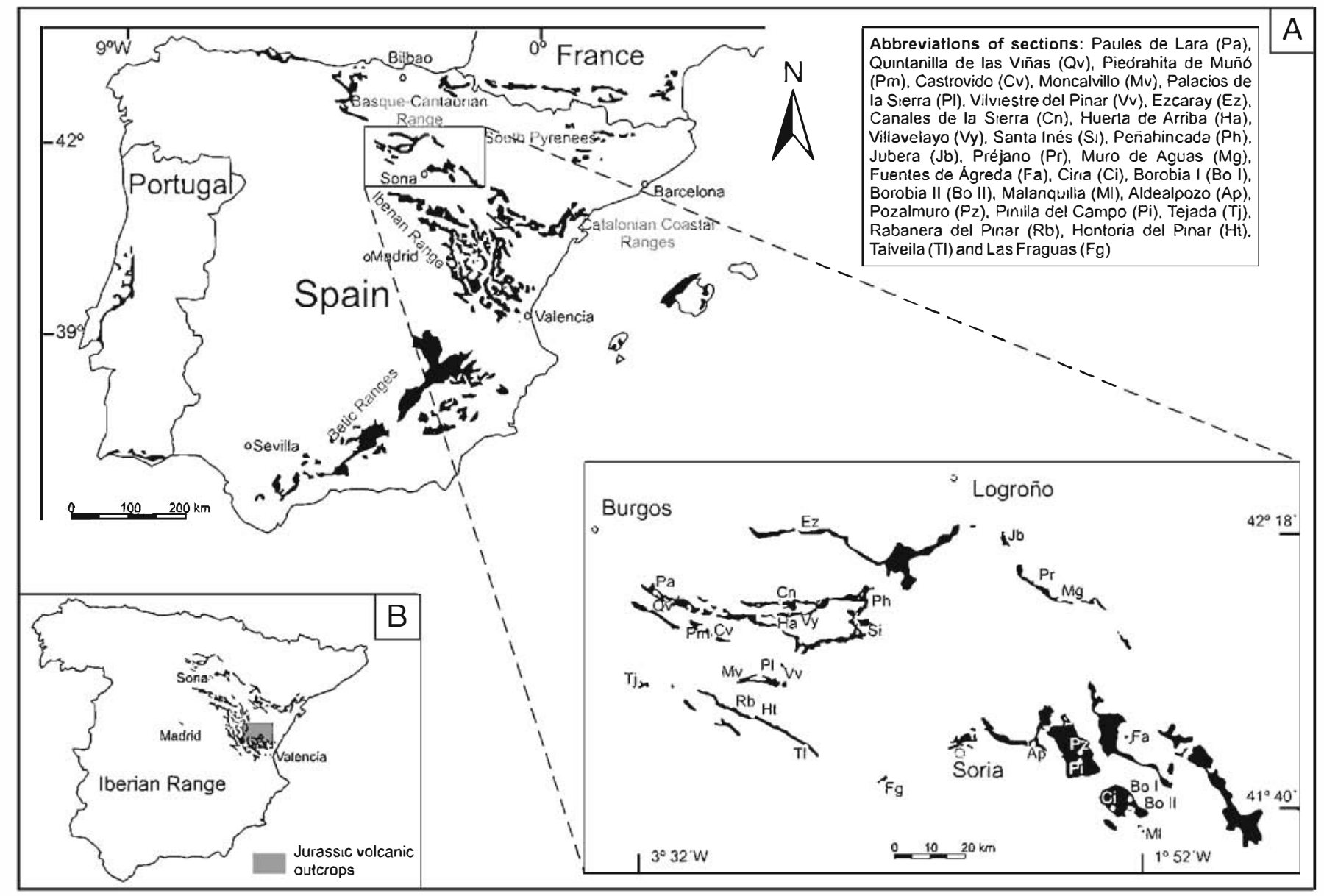

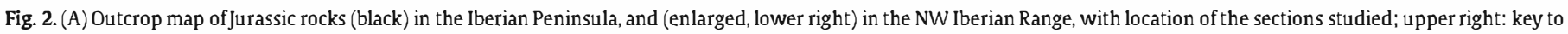
abbreviations of sections names (see also Appendix A). (B) Location of area of exposed Jurassic volcanic/volcaniclastic rocks in the SE Iberian Range.

formed as a pull-apart basin on the northern border of the left-lateral Mesozoic Newfoundland-Gibraltar-W Tethys transform connexion between Africa and Iberia (e.g. Dewey et al., 1989). The W-Portuguese
Lusitanian Basin, in turn, records the stepwise northward propagation of rifting, and the subsequent opening of the North Atlantic Ocean, since Middle Jurassic times (e.g. Wilson, 1988).

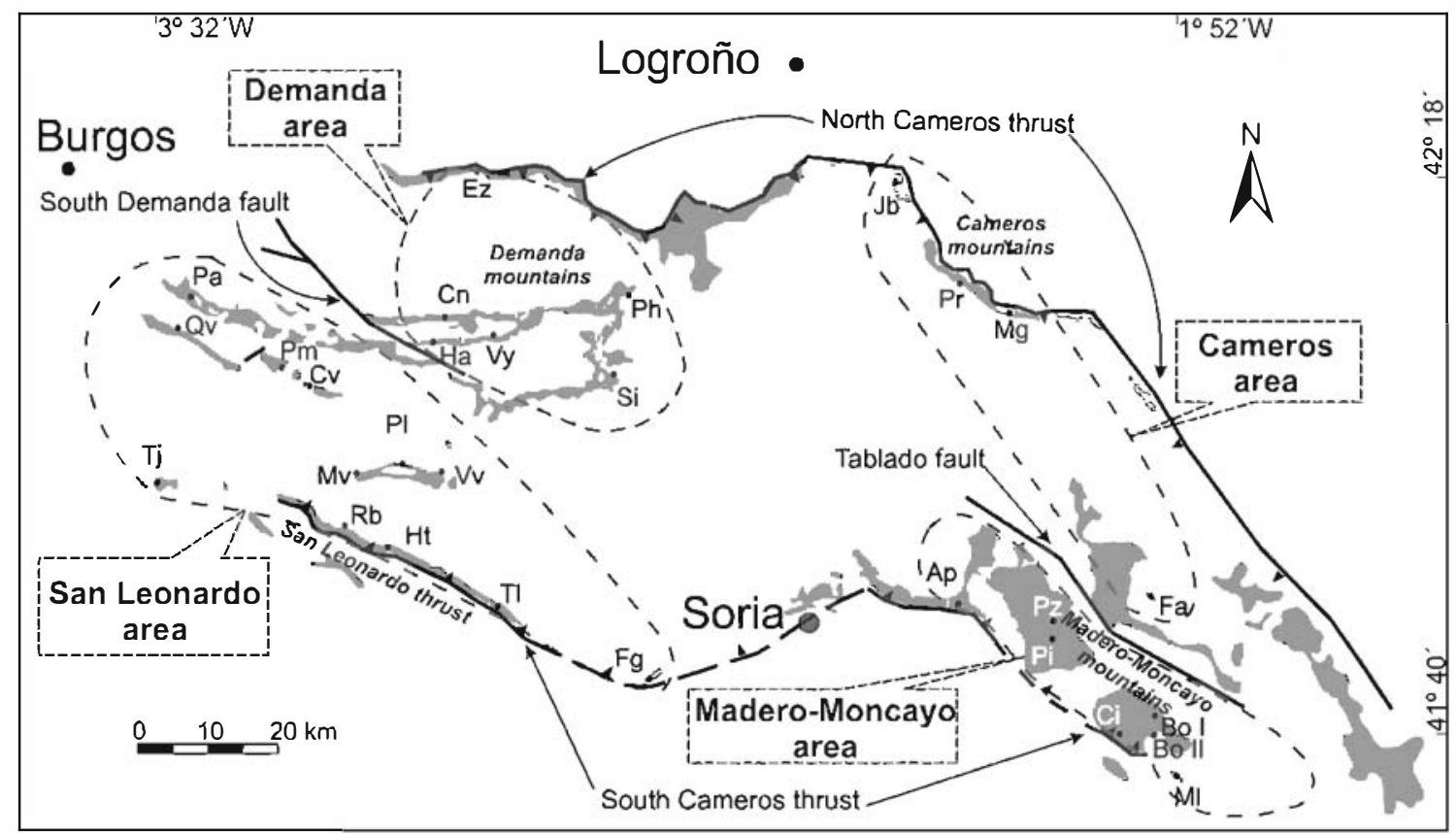

Fig. 3. Location of the four major areas distinguished in this study, and main bounding faults. Abbreviations (section names) as in Fig. 2 A. 
Several successive Jurassic extensional phases are reported from the Betic Cordillera (External Zones, S-Iberian domain) (Azañón et al.. 2002; Martín-Algarra et al., 2004). A major faulting event occurred during the Pliensbachian (around the Carixian-Domerian boundary), resulting in the break-up and drowning of the shallow-water carbonate platform. A second phase of active normal faulting, documented by significant differential subsidence, occurred during the Domerian to Bathonian time interval, and was followed by a homogenization of depositional facies. In the Middle Jurassic, marked volcanic activity is reported from the same area (e.g. Orti and Vaquer, 1980).

Gómez and Goy (2005) defined in the Iberian Basin a major transgressive-regressive cycle ranging from the late Norian to the Middle Aalenian, which they correlated with the Ligurian Cycle of de Graciansky et al. (1998) and Jacquin and de Graciansky (1998a). This cycle comprises four subcycles of 6 to 12 Ma duration (LJ-1 to LJ-4). From subcycle $\mathrm{LJ}-1$ to $\mathrm{LJ}-3$ (evaporites passing upward into interbedded marine carbonates and marls) spanning the late Norian to middle Toarcian interval, the transgressive intervals became progressively longer reflecting progressive flooding of the westernmost periTethyan platforms, whilst the corresponding regressive hemicycles became shorter. This trend was followed by an overall shallowing during subcycle $\mathrm{LJ}-4$ (alternating marls and limestones passing upward into bioclastic limestones) spanning the late Toarcian and the Aalenian p.p. Coeval alkaline volcanism was interpreted by Gómez and Goy (2005) as indicating a peak in extentional tectonic activity, related to the opening of the Atlantic-Alpine-Tethys rift system. Moreover, in the Aalenian portion of $\mathrm{LJ}-4$ several authors recognized major unconf ormities (e.g. Ureta, 1985; Goy and Ureta, 1990; GarcíaFrank et al., 2006b; García-Frank, 2007).

\section{Methods}

A detailed (layer-by-layer) analysis has been performed on 29 uppermost Toarcian to lowermost Bajocian stratigraphic sections in the NW sector of the Iberian Range (see Figs. 2 and 3, and Appendix A). Limestones have been classified according to Dunham (1962). Biostratigraphical and lithological analyses allowed correlation among the sections, and the definition of unconformity-bounded sequences. As far as sequence definition is concerned, we have followed Van Wagoner et al. (1988). Sequence subdivision follows the hierarchy of Vail et al. ( 1991), according to which 2nd, 3rd and higherorder sequences span 3-50, 0.5-3 and $<0.5$ Ma respectively. Dating of the sequences is based on ammonite biostratigraphy. The study of 525 successive ammonoid assemblages has allowed to assess the chronostratigraphic range of the unconformity-bounded sequences, and their boundaries, with a precision of $0.5 \mathrm{Ma}$ approx. (Garcia-Frank, 2007). The ammonoid biostratigraphic scale used in this study is the one proposed by Henriques et al. (1996), based on data from the Iberian, Betic and Lusitanian basins (see also Sandoval et al., 2001). Absolute ages follow the geochronological scale of Gradstein and Ogg (2004).

The established sequences have an estimated duration of 0.5 to $2 \mathrm{Ma}$, and typically consist of a deepening-upwards and a shallowingupwards hemicycle. It is, however, impossible to recognize in most of our cycles the detailed internal architecture characterizing a 'transgressive/regressive (T/R) facies cycle' sensu Jacquin and Graciansky (1998a,b).

In order to display the spatial and temporal evolution of Aalenian deposits, isopach maps have been drawn for each sequence recognized in the succession. Comparison of the isopach maps referring to successive sequences then allows to assess variations in sediment accumulation rates (present-day sediment thickness/Ma) over the study area.

\section{Stratigraphic sequences}

Four main areas can be distinguished, in the Middle Jurassic record of NW Iberian Range according to facies development, thickness distribution and fossil content (Fig. 3). They are informally denominated: Demanda area (NW), San Leonardo area (SW), MaderoMoncayo area (SE) and Cameros area (NE). The San Leonardo and Madero-Moncayo areas can be further divided into a western and eastern sub-area, based on changes in both thickness and facies. In the San Leonardo area, the thinnest sections appear in the north, whereas in the Madero-Moncayo area they occur in the west.

A comparison of the Toarcian-Bajocian lithostratigraphic units in the NW Iberian Range, such as defined by Gómez et al. (2003) and Gómez and Fernández-López (2004), and as used in this study, is shown in Fig. 4.

In the Demanda, San Leonardo and Madero-Moncayo areas, the studied deposits consist of limestones and marls of the Turmiel, Casinos and El Pedregal formations (García-Frank, 2007). The lower part of the succession is represented by an alternation of lime mudstone-wackestone and marls of the Turmiel Formation; the middle and upper parts correspond to the Casinos Formation and consist of mudstone-wackestone and occasional bioclastic wackestonepackstone, generally with thin marl interbeds; the uppermost part

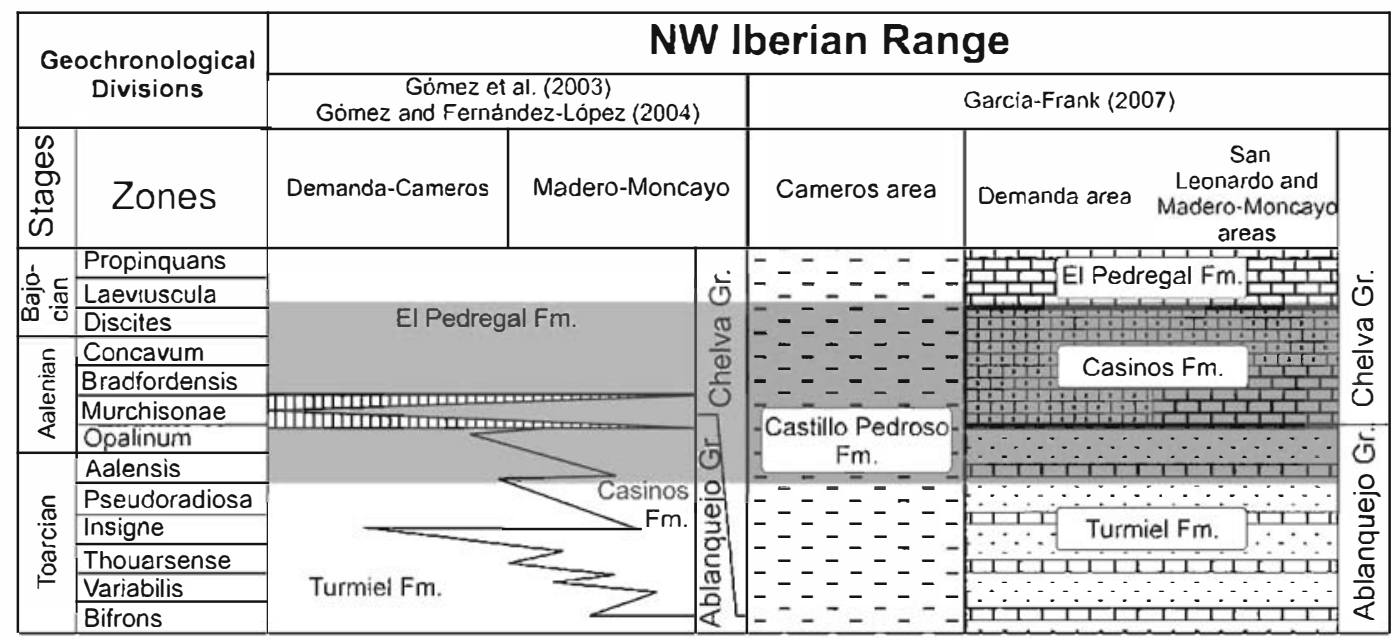

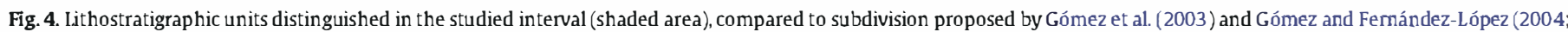
condensed levels marked by vertical lines). 

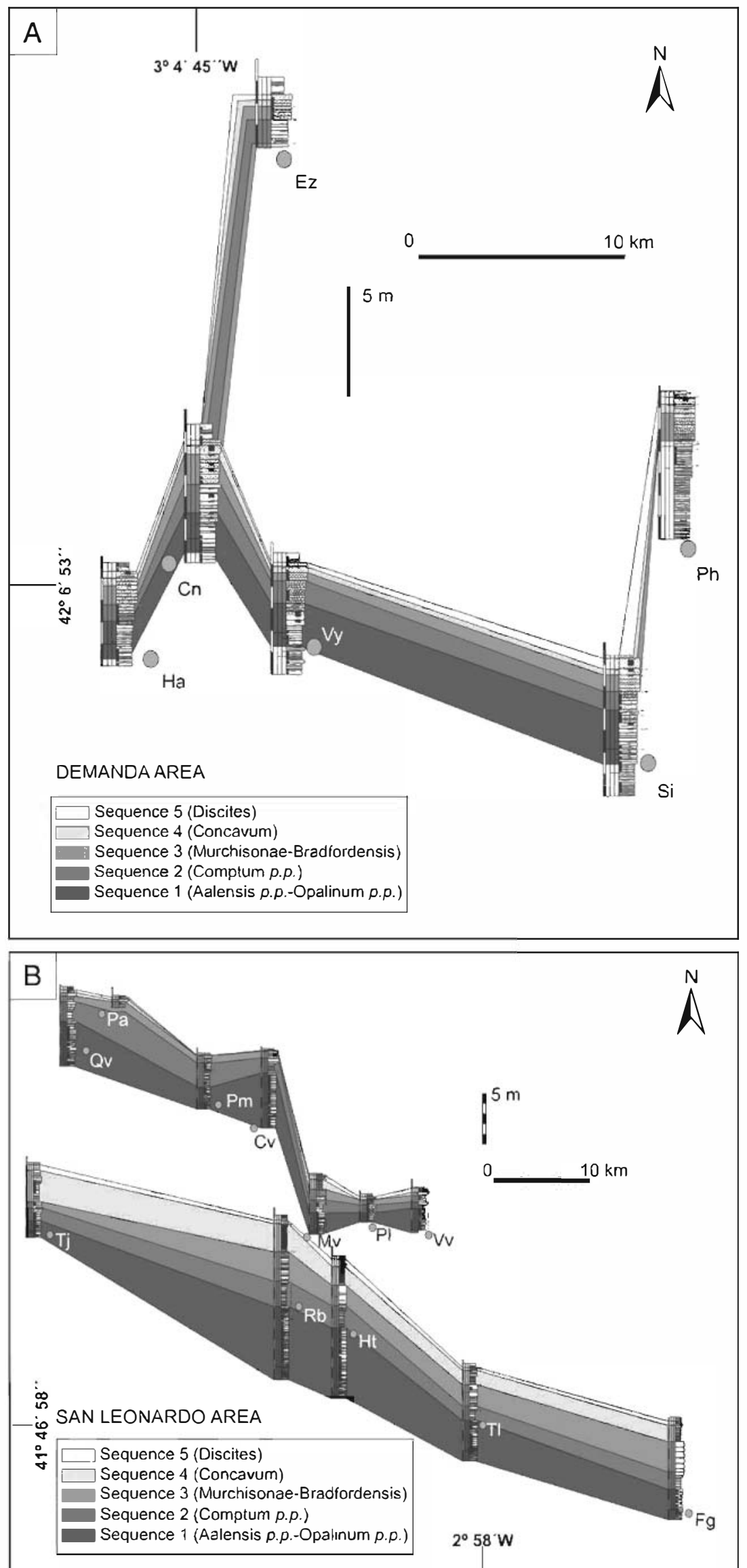

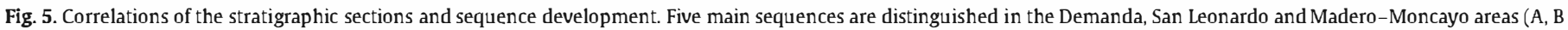
and $C$ respectively), whereas twelve occur in the Cameros area (D); abbreviations (section names) as in Fig. $2 \mathrm{~A}$. 

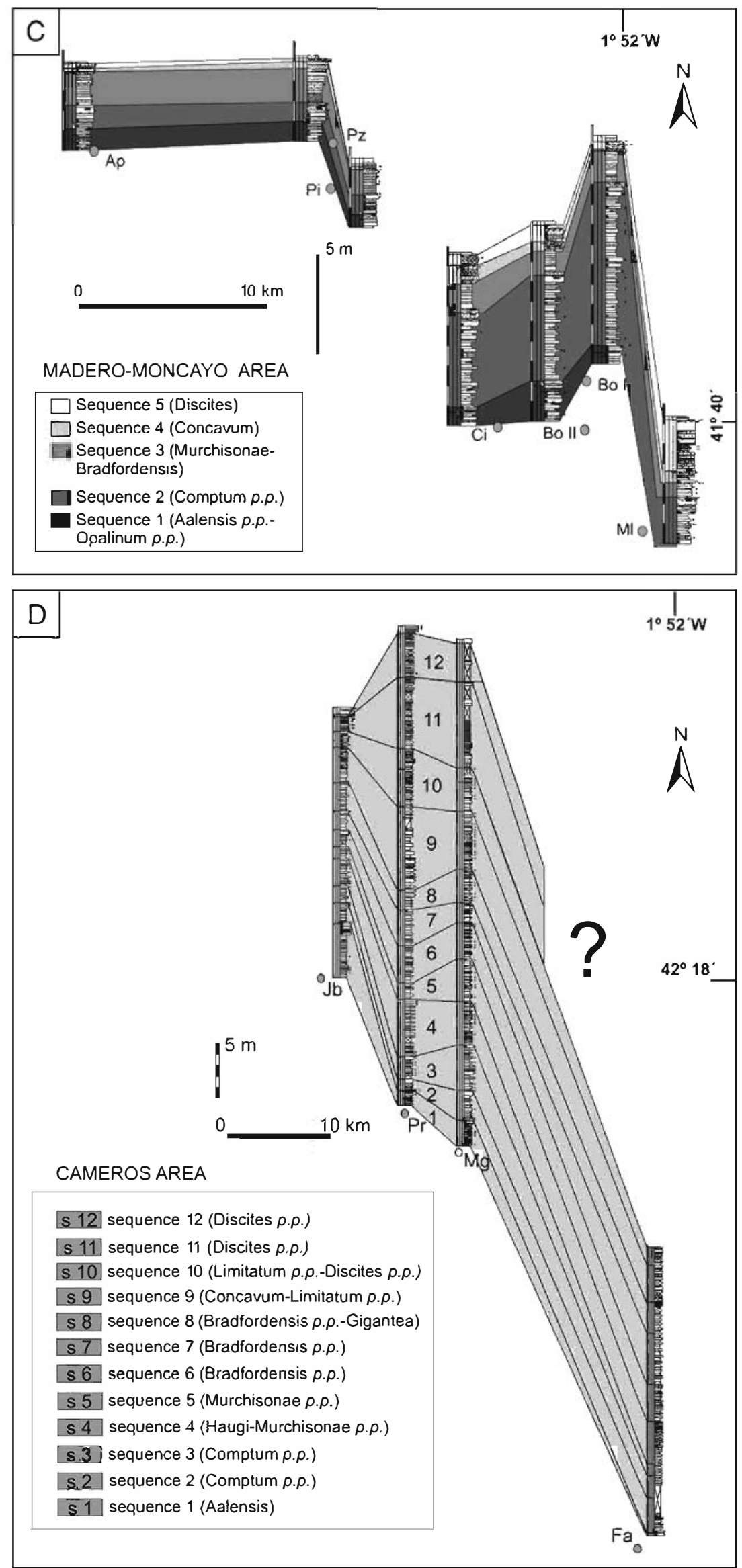

Fig. 5 (continued). 

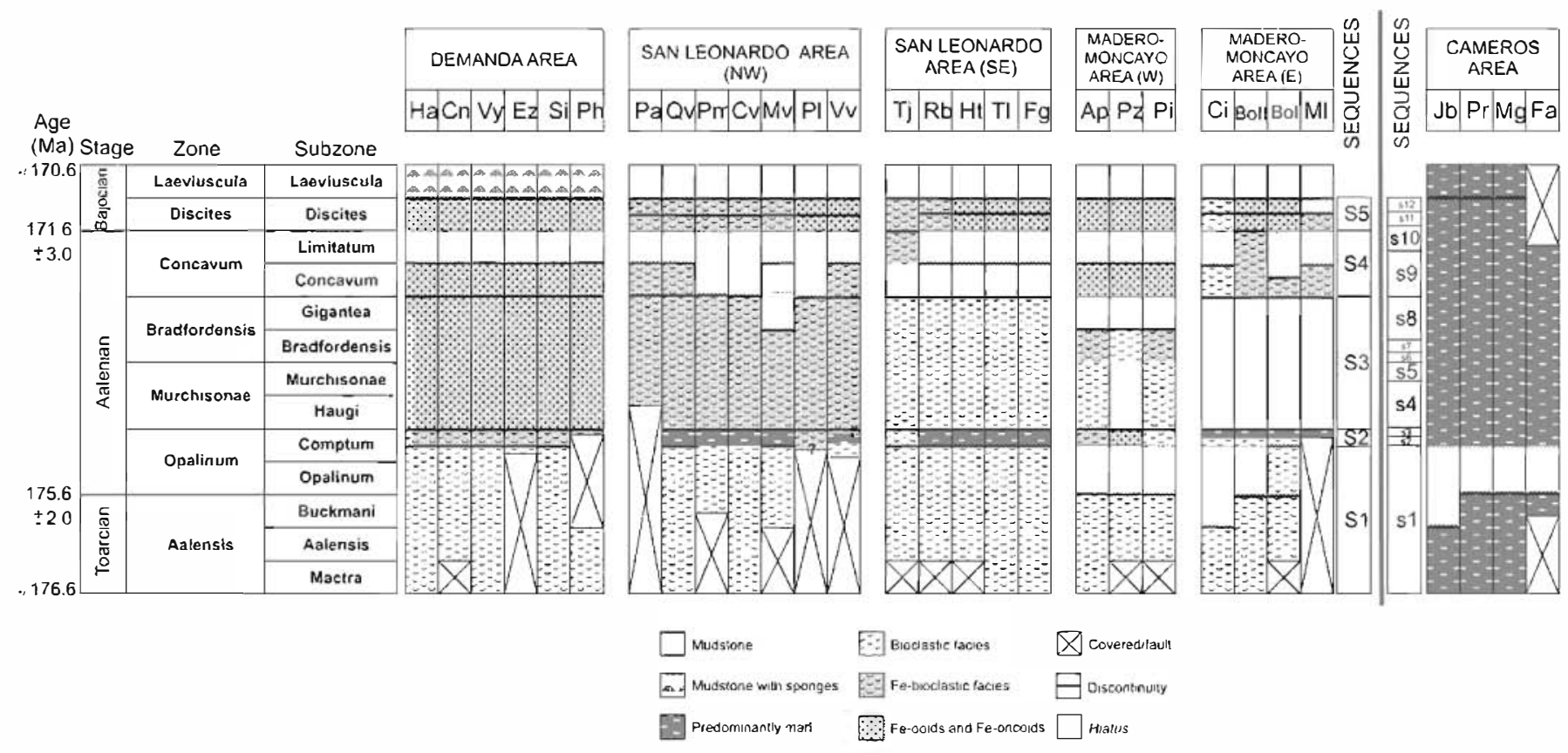

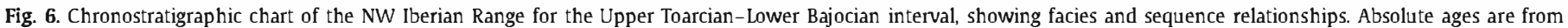
Gradstein and Ogg (2004). Abbreviations (section names) as in Fig. 2A.

is represented by lime mudstones and wackestones of the El Pedregal Formation.

Facies pattern and biostratigraphic successions observed in the Cameros area reveal a striking similarity to the Basque-Cantabrian Basin, about $100 \mathrm{~km}$ to the NW (Fernández-López et al., 1988; Aurell et al., 2002). Therefore, we propose to use the term Castillo Pedroso Formation for the rhythmic alternation of limestones (mst-wst) and organic-rich dark grey marls (García-Frank, 2007) in the Cameros area (see Fig. 4).

In the Demanda area, the limestone (wst-pst) package representing the Casinos Fm contains abundant iron-coated particles ( $\mathrm{Fe}$ cortoids, Fe-oncoids, Fe-ooids and Fe-grapestones), in marked contrast to the other sectors of the study area (Garcia-Frank, 2007), where iron-coated particles usually occur exclusively in the topmost part of the formation.

General condensed sedimentation and the presence of five unconformity-bounded sequences characterize the Demanda, San Leonardo and Madero-Moncayo areas, whereas in the Cameros area a thicker succession is observed, and twelve coarsening-upward sequences can be distinguished (Fig. 5A, B and C vs. D; Fig. 6). In the latter area, two main unconformities are detected, within the lower portion and at the top of the succession respectively.

\subsection{Stratigraphic sequences in the Demanda, San Leonardo and Madero- Moncayo areas}

In the Demanda, San Leonardo and Madero-Moncayo areas, exposures of Jurassic rocks occur along NW/SE-trending bands. In the measured sections, the identified sequences correspond to a time interval ranging from 0.5 to $2 \mathrm{Ma}$ (3rd-order sequences sensu Vail et al., 1991).

The chronostratigraphic divisions used for establishing the range of each sequence are those of the Standard Scale (Gradstein and Ogg, 2004), and are shown in Fig. 6. The five sequences cover the Upper Toarcian to the Lower Bajocian interval (see Fig. 6 and Table 1). Table 2 summarizes the main features, while Fig. 7 schematically represents the development of each sequence within the different areas.

Sequence 1 (S1) consists of marl and marly limestone alternating with bioclastic wackestone-mudstone throughout the three areas
(Fig. 6), and varies in thickness from $0.8 \mathrm{~m}$ to $6.6 \mathrm{~m}$ (Fig. 7). The top of the sequence is generally erosional, although it can be represented locally ( $\mathrm{N}$ part of the San Leonardo area: Piedrahita de Muñó, Castrovido, Palacios de la Sierra and Vilviestre sections) by a facies change from thick-bedded lime wackestone to alternating mudstone and marl. S1 is thickest in the Demanda and San Leonardo areas and condensed in the Madero-Moncayo area. The lower part (lime mstwst and marls with ammonoids, bivalves, and occasionally, nautiloids, brachiopods and gastropods) represents the deepening hemicycle, whereas lime wackestone-packstone in the upper part records the shallowing phase. The fossil content in this upper part is diverse: ammonoids, bivalves, brachiopods, echinoids, serpulids, gastropods and, occasionally, belemnites. In the SW sector of the San Leonardo area (Tejada and Rabanera sections) corals and sponges are very common.

Sequence 2 (S2) is typically marl dominated, with interbedded lime wackestone-mudstone in the lower part, and lime wackestonepackstone in the upper part. In the Demanda area, Fe-bioclastic limestone prevails. In the lower part of the sequence, fossils are scarce and include ammonoids, nautiloids, brachiopods and trace fossils such as Chondrites. The upper part of the sequence is more bioclastic, contains ammonoids, bivalves, serpulids, brachiopods, echinoderm plates and gastropods, as well as trace fossils such as Thalassinoides. In the San Leonardo area, corals and sponges also appear in the upper part of the sequence. The lower boundary is an unconformity, dated as intra-Comptum in age. In the Madero-Moncayo area, this unconformity is represented by a hiatus that spans the Opalinum and,

Table 1

Chronostratigraphic range of sequences defined in the Demanda, San Leonardo and Madero-Moncayo areas

\begin{tabular}{lll}
\hline \multicolumn{2}{l}{ Demanda, San Leonardo and Madero-Moncayo areas } \\
\hline Sequences & Chronozones & Stage \\
\hline Sequence 5 & Discites Z. & Lower Bajocian \\
Sequence 4 & Concavum Z. & Upper Aalenian \\
Sequence 3 & Murchisonae Z.-Bradfordensis Z. & Middle Aalenian \\
Sequence 2 & Comptum Sz. P.p. & Lower Aalenian \\
Sequence 1 & Aalensis Z p.p.-Comptum Sz. p.p & Upper Toarcian to Lower Aalenian \\
\hline
\end{tabular}


Table 2

Summary of the main stratigraphic features of the sequences defined in the Demanda (D), San Leonardo (SL) and Madero-Moncayo (M-M) areas

\begin{tabular}{|c|c|c|c|c|c|c|}
\hline \multicolumn{3}{|c|}{$\begin{array}{l}\text { Sequences in areas Demanda, San Leonardo and } \\
\text { Madero-Moncayo }\end{array}$} & \multirow{2}{*}{$\begin{array}{l}\text { Main lithology } \\
\text { L/M }\end{array}$} & \multirow{2}{*}{$\begin{array}{l}\text { Thickness average } \\
\text { values }(\mathrm{m})\end{array}$} & \multirow{2}{*}{$\begin{array}{l}\text { Upper boundary } \\
\text { Erosive surface }\end{array}$} & \multirow{2}{*}{$\begin{array}{l}\text { Characteristics } \\
\text { Variation in thickness but similar }\end{array}$} \\
\hline Aalensis & Sequence 1: Aalensis & SL $(\mathrm{N})$ & & & & \\
\hline \multirow[t]{9}{*}{ p.p.-Opalinum } & p.p.-Comptum p.p & SL $(S)$ & $\mathrm{L} / \mathrm{M}$ & 6.6 & Erosive surface & facies (alternation of limestones \\
\hline & & $\mathrm{M}-\mathrm{M}(\mathrm{E})$ & $\mathrm{L}$ & 0.8 & Erosive surface & and marl) throughout the different \\
\hline & & $\mathrm{M}-\mathrm{M}(\mathrm{W})$ & $\mathrm{L} / \mathrm{M}$ & 1 & Erosive surface & areas \\
\hline & & D & $\mathrm{L} / \mathrm{M}$ & 2 & Erosive surface & \\
\hline & Sequence 2: Comptum p.p. & $\mathrm{SL}(\mathrm{N})$ & M & 1.5 & Erosive surface & Mostly represented by two \\
\hline & & $\mathrm{SL}(\mathrm{S})$ & M & 2.5 & Erosive surface, HG & subcycles (deepening-upwards \\
\hline & & $\mathrm{M}-\mathrm{M}(\mathrm{E})$ & M & 5.5 & Erosive surface & and shallowing-upwards) \\
\hline & & $\mathrm{M}-\mathrm{M}(\mathrm{W})$ & $\mathrm{L}$ & 1 & Erosive surface & \\
\hline & & $\mathrm{D}$ & $\mathrm{L}$ & 1 & Erosive surface & \\
\hline Murchisonae- & Sequence 3: Murchisonae- & $\mathrm{SL}(\mathrm{N})$ & $\mathrm{L}$ & 0.7 & Erosive surface, HG & Thickness rather homogeneous. \\
\hline \multirow[t]{4}{*}{ Bradfordensis } & Bradfordensis & $\mathrm{SL}(\mathrm{S})$ & $\mathrm{L}$ & 2.1 & Erosive surface & Facies changes from mudstones \\
\hline & & $\mathrm{M}-\mathrm{M}(\mathrm{E})$ & $\mathrm{L}$ & 1.3 & HG & to bioclastic limestones and even to \\
\hline & & $\mathrm{M}-\mathrm{M}(\mathrm{W})$ & $\mathrm{L}$ & 1.6 & Erosive surface & Fe-bioclastic or Fe-oncolitic/oolitic \\
\hline & & $\mathrm{D}$ & $\mathrm{L}$ & 0.9 & Erosive surface & limestones \\
\hline \multirow[t]{5}{*}{ Concavum } & Sequence 4: Concavum & $\mathrm{SL}(\mathrm{N})$ & $\mathrm{L}$ & 0.3 & Erosive surface, HG & Heterogeneous facies development: \\
\hline & & $\mathrm{SL}(\mathrm{S})$ & $\mathrm{M} / \mathrm{L}$ or $\mathrm{L}$ & 2.2 & Erosive surface, HG & mudstones, Fe-bioclastic limestones, \\
\hline & & $\mathrm{M}-\mathrm{M}(\mathrm{E})$ & $\mathrm{L}$ & 0.5 & Erosive surface, HG & Fe-oncolitic/oolitic limestones \\
\hline & & $\mathrm{M}-\mathrm{M}(\mathrm{W})$ & $\mathrm{L}$ & 0.3 & Erosive surface & \\
\hline & & $\mathrm{D}$ & $\mathrm{L}$ & 0.4 & Erosive surface & \\
\hline \multirow[t]{5}{*}{ Discites } & Sequence 5: Discites & $\mathrm{SL}(\mathrm{N})$ & $\mathrm{L}$ & 0.3 & $\begin{array}{l}\text { Erosive surface that enhances } \\
\text { a facies change from Fe-rich } \\
\text { limestones to mudstones in the } \\
\text { next sequence }\end{array}$ & $\begin{array}{l}\text { Sedimentary thickness fairly } \\
\text { condensed. Facies change } \\
\text { from Fe-bioclastic limestones to } \\
\text { Fe-oncolitic/oolitic limestones }\end{array}$ \\
\hline & & $\mathrm{SL}(\mathrm{S})$ & $\mathrm{L}$ & 0.5 & Erosive surface & \\
\hline & & $\mathrm{M}-\mathrm{M}(\mathrm{E})$ & $\mathrm{L}$ & 1.1 & Erosive surface, HG & \\
\hline & & $\mathrm{M}-\mathrm{M}(\mathrm{W})$ & $\mathrm{L}$ & 0.2 & Erosive surface & \\
\hline & & $\mathrm{D}$ & $\mathrm{L}$ & 0.3 & Erosive surface & \\
\hline
\end{tabular}

Abbreviations: $\mathrm{L}=$ limestones; $\mathrm{M}=$ marl; $\mathrm{HG}=$ hard ground.

presumably, part of the Comptum Biochron. Water depth increased during deposition of the lower marl sequence (deepening hemicycle), but shallowed towards the top, as indicated by an increase in number and thickness of limestone beds (shallowing hemicycle). Sequence thickness ranges from $1 \mathrm{~m}$ to $5.5 \mathrm{~m}$. Thickness is greatest in the eastern sub-area of the Madero-Moncayo area and least in the western subarea of the same area. Considerably reduced thicknesses also characterize the Demanda area. The top surface of S2 is always erosional, although in the southern part of the San Leonardo area, borings and crusts indicate the development of hard grounds.

Sequence 3 (S3) generally is represented by thick-bedded bioclastic packstones, with the exception of the eastern part of the MaderoMoncayo area where barren lime mudstones prevail. In the former, coated grains and bioclasts are affected to variable degrees by ferrugination, and macrofossils include ammonoids, bivalves, brachiopods, echinoderm plates and serpulids. In the San Leonardo area sponges and corals occur as well. The lower boundary is an unconformity which falls within the Opalinum Z/Murchisonae $\mathrm{Z}$ boundary interval. Over the study area there is little variation in thickness $(0.7$ to $2.1 \mathrm{~m})$. The upper boundary is an erosive surface, which is marked in some sections of the San Leonardo and MaderoMoncayo areas by a hard ground with borings and encrusting organisms. This cycle is notably asymmetrical, but in contrast to S2 the deepening phase is restricted to a thin lag deposit, or two superposed hard grounds ( $S$ part of the San Leonardo area), and the record of the shallowing phase represents almost the total of the cycle thickness.

Sequence 4 (S4) is predominantly made up of limestone with common ferriferous grains, except for the SE sector of the San Leonardo area where thin beds of mudstone alternate with marl. Ammonoids, belemnites, bivalves, brachiopods, echinoderm plates and gastropods are very abundant. The lower boundary corresponds to an unconformity represented by a hiatus that spans Concavum Biochron p.p. In some sections of the San Leonardo and MaderoMoncayo areas, the hiatus also includes Gigantea, Concavum and Limitatum Biochrons. The upper surface locally shows erosion, bioturbation, and/or encrustation. Thickness varies between 0.3 and $2.2 \mathrm{~m}$. Sequence development is virtually the same as in S3. Thin lag deposits or hard grounds represent the deepening hemicycle, and bioclastic limestones the shallowing one.

Sequence 5 (S5) is constituted by lime packstone-wackestone with abundant Fe-coated grains and bioclasts. This lithofacies prevails throughout the examined area, although in the SE part of the MaderoMoncayo area there are two exceptions: in the Ciria section the bioclastic limestones show a low degree of ferruginization, and in the Malanquilla section mudstones occur in the upper part of S5. The fossil content is rather similar to that of the previous sequence. The lower boundary is an unconformity that coincides with the Concavum Z/Discites Z boundary. In most sections, this unconformity is represented by a hiatus that spans from at least the Limitatum Biochron to, locally, the Concavum and Limitatum Biochrons. Its thickness ranges from 0.2 to $1.1 \mathrm{~m}$, with the exception of Malanquilla section $(2.5 \mathrm{~m})$. The upper surface is a hard ground that displays (bio)erosion and encrustation. The cycle is broadly symmetrical, with the lower half represented by lime wackestone and the upper one by bioclastic and, in places crossedbedded, ferruginous limestones. The sequence is commonly topped by an erosional surface.

\subsection{Stratigraphic sequences in the Cameros area}

The succession in this area differs markedly from the others described above, both in terms of overall thickness and facies development. Facies closely resemble the contemporaneous basinal upper portion of the Castillo Pedroso Formation in the BasqueCantabrian Basin (Fernández-López et al., 1988; Aurell et al., 2002). Bedding is regular, as is common in hemipelagic environments.

Outcrops are aligned along a NNW-SSE trend, parallel to the 'North Cameros thrust' (see Fig. 3). In the late Toarcian to early Bajocian interval, 12 stratigraphic sequences have been distinguished in this area (see Fig. 6 and Table 3). All sequences coarsen upwards and they are not bounded by major unconformities, except for the lower portion and the top of the succession. Each sequence records about 


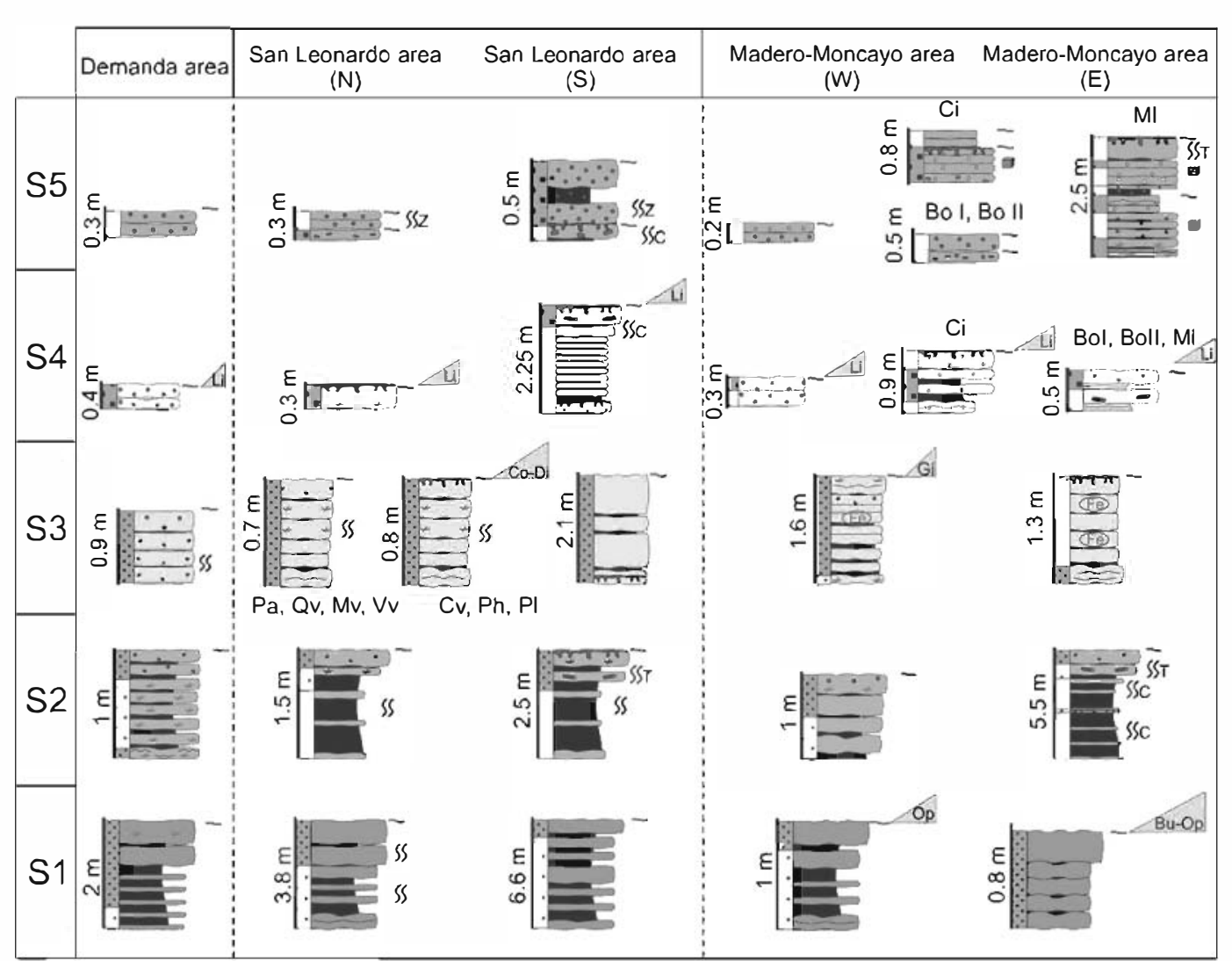

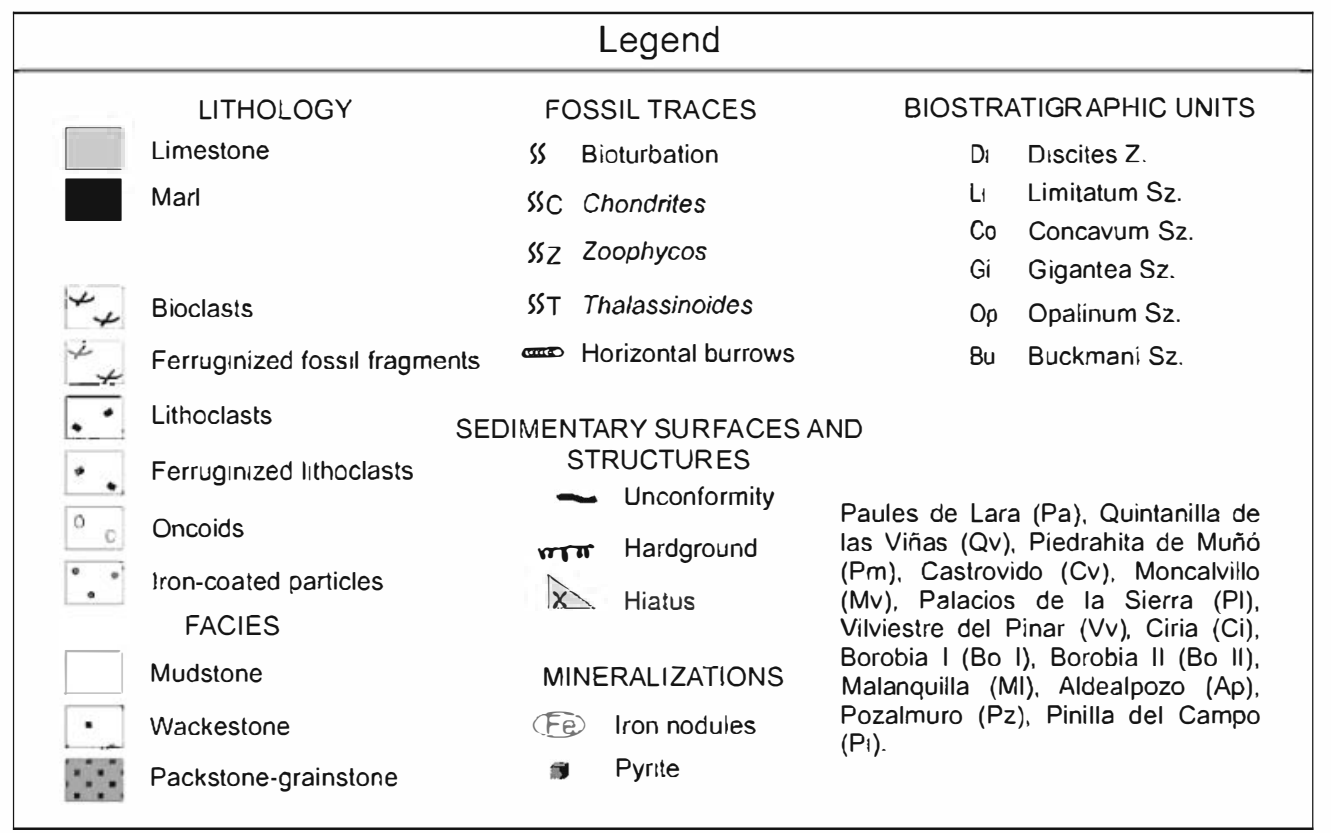

Fig. 7. Synthetic sequence development in the Demanda, San Leonardo and Madero-Moncayo areas.

$0.5 \mathrm{Ma}$, corresponding to 3rd-order and 4th-order sequences sensu Vail et al. (1991).

Table 4 summarizes the main features, while in Fig. 8 the development of each sequence within this area is schematically represented. In the Cameros area, a more continuous and uniform sedimentation gives rise to a more expanded record than in the areas previously described.

Sequence 1 ( $\mathrm{s} 1$ ) consists of a thickening-upwards sequence of lime mudstone-wackestone interbedded with marl and marly limestone. Average thickness is $3.5 \mathrm{~m}$. The lower part of s1 is dominantly marly with thin interbeds of mudstone and is rich in ammonoids and belemnites, whereas the upper part is more bioclastic and contains more diverse benthic fossils, including bivalves, echinoderms and brachiopods, as well as ammonoids and abundant horizontal and vertical trace fossils. The sequence is capped by two superposed erosive surfaces marked by iron crusts.

Sequence 2 (s2) consists of a thickening-upward alternation of mudstone and marly limestone. The lower boundary is generally represented by a hiatus that spans at least the Opalinum Biochron, except for the NW part, where this hiatus may also include the 


\begin{tabular}{lll}
\hline Cameros area & & \\
\hline Sequences & Chronozones & Stage \\
\hline s11 and s12 & Discites Z. p.p. & Lower Bajocian \\
s10 & Limitatum Sz. p.p.-Discites Z. p.p. & $\begin{array}{l}\text { Uppermost Aalenian } \\
\text { to Lowermost Bajocian }\end{array}$ \\
s9 & Concavum Sz.- Limitatum Sz. p.p. & Upper Aalenian \\
s6, s7 and s8 & Bradfordensis Sz.p.p.-Gigantea Sz. & Middle Aalenian. \\
s4 and s5 & Haugi Sz.-Murchisonae Sz.p.p. & Middle Aalenian \\
s2 and s3 & Comptum Sz. p.p. & Lower Aalenian (Lower \\
& & Middle Jurassic) \\
s1 & Aalensis Z. & Uppermost Toarcian \\
& & (Upper Lower Jurassic) \\
\hline
\end{tabular}

Buckmani Biochron. Thickness averages $2 \mathrm{~m}$, the lowest value of all the sequences in this region. In the upper part of $s 2$ scattered ferruginous bioclasts appear.

Sequence 3 (s3) is mostly marl with thickening-upwards interbeds of lime mudstone-wackestone. Trace fossils such as Chondrites are abundant. The average thickness is $3 \mathrm{~m}$.

In Sequence 4 (s4) the marl content increases upward in the lower part. Bioturbation patterns suggest a deepening-upward trend. The upper part is represented mainly by lime mudstone-wackestones containing brachiopods, bivalves and slightly ferruginous bioclasts. Average thickness is $4.5 \mathrm{~m}$.

Sequence 5 (s5) is mostly marl with thin interbeds of limestone. The lower part shows a deepening-upward trend (iron nodules interbedded in the marls, scarce bioturbation represented by Chondrites and nektonic fossils), whereas throughout the upper portion the degree of bioturbation increases progressively. This upper part includes thicker mudstone-wackestone beds with brachiopods and bivalves, and reflects a shallowing-upward trend. Its thickness is $2.5 \mathrm{~m}$.

Sequence 6 (s6) consists of interbedded limestones and marls, with the proportion of the latter decreasing upwards. It contains echinoderm plates, brachiopods, bivalves and ammonoids. Average thickness is close to $3.5 \mathrm{~m}$.

Sequence 7 ( $\mathrm{s} 7$ ) consists of alternating marls and marly limestones displaying a thickening-upwards trend. Thickness is $2.5 \mathrm{~m}$.

Sequence 8 (s8) is similar to $\mathrm{s} 6$, and consists of an alternation of marl and marly limestone. The number of carbonate beds increases upward and they become more bioclastic (lime wackestone-packstone with abundant bioturbation traces) indicating a shallowing-upwards trend. Chondrites is abundant within the limestone. Thickness averages $3 \mathrm{~m}$.

Sequence 9 (s9) is a roughly $5.5 \mathrm{~m}$ thick, and is made of an alternation of thickening-upward lime mudstone-wackestone and marl, the proportion of which is, however, less than in the previous

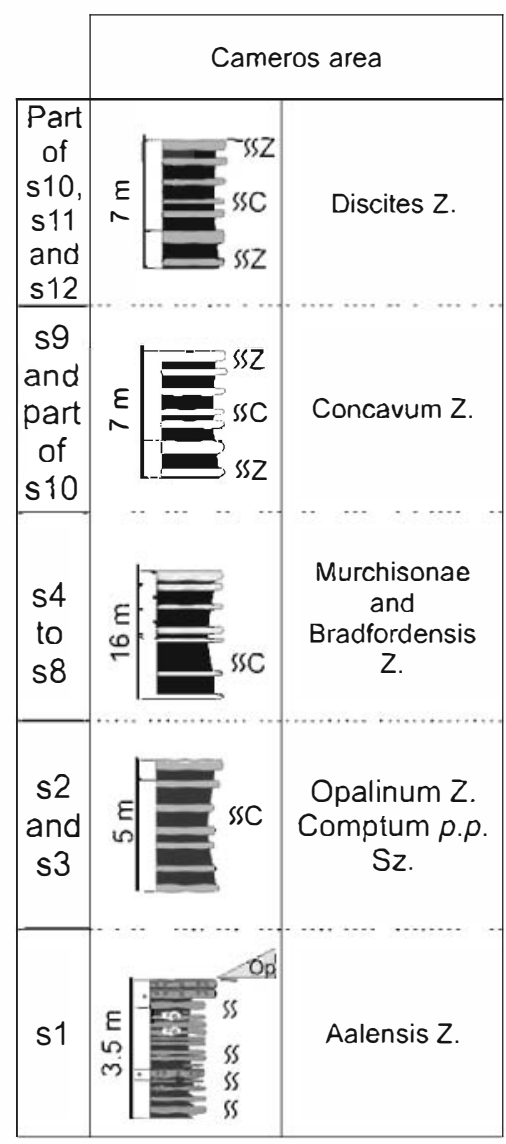

Fig. 8. Synthetic sequence development in the Cameros area. Legend for the sequences is the same as in Fig. 7.

sequences. Trace fossils, such as Zoophycos, frequently occur in the upper parts of limestone beds, and are locally associated with iron nodules.

In Sequence 10 (s10), thickening-upwards limestone beds alternate with subordinate marl, and the upper portion of the limestone beds contain common Zoophycos. A few iron nodules appear at the top of s10 and an Fe-crust is present in the Jubera section. Average thickness is $3 \mathrm{~m}$.

Sequence 11 (s11) is an alternation of thickening-upward lime mudstone and marl, with a higher proportion of marl in the Muro de Aguas and Préjano sections (central portion of the area). In the Jubera section, to the NW, s11 is represented by bioclastic wackestonepackstone. The sequence ranges in thickness from $5 \mathrm{~m}$ in the central area to $1.5 \mathrm{~m}$ in the northwest.

Table 4

Summary of the main stratigraphic features of the sequences defined in the Cameros area

\begin{tabular}{|c|c|c|c|c|}
\hline \multicolumn{2}{|c|}{ Sequences in Cameros area } & \multirow{2}{*}{ Main lithology } & \multirow{2}{*}{$\begin{array}{l}\text { Thickness average values }(\mathrm{m}) \\
3.5\end{array}$} & \multirow{2}{*}{$\begin{array}{l}\text { Characteristics } \\
\text { Greatest thickness in the NW area. Upper boundary is an erosive surface }\end{array}$} \\
\hline s1 & Aalensis & & & \\
\hline$s 2$ & Comptum p.p. & $\mathrm{L} / \mathrm{M}$ & 2 & This is the thinnest sequence \\
\hline s3 & Comptum p.p. & $\mathrm{M} / \mathrm{L}$ & 3 & Marly sedimentation predominates. Greatest thickness in the central area. \\
\hline s4 & Haugi-Murchisonae p.p. & $\mathrm{M} / \mathrm{L}$ & 4.5 & Thickness increases \\
\hline s5 & Murchisonae p.p. & $\mathrm{M} / \mathrm{L}$ & 2.5 & Thickness notable reduced \\
\hline s6 & Bradfordensis p.p. & M & 3.5 & Marly sedimentation dominant \\
\hline s7 & Bradfordensis p.p. & M & 2.5 & Marly sedimentation dominant \\
\hline s8 & Bradfordensis p.p-Cigantea & $\mathrm{M} / \mathrm{L}$ & 3 & Marly sedimentation dominant \\
\hline s9 & Concavum-Limitatum p.p. & $\mathrm{L} / \mathrm{M}$ & 5.5 & Notable thickness increase. Presence of Zoophycos \\
\hline s10 & Limitatum p.p.-Discites p.p. & $\mathrm{L} / \mathrm{M}$ & 3 & $\begin{array}{l}\text { Increased carbonate content. Presence of Zoophycos. Iron nodules appear at the top } \\
\text { of the sequence, and Fe-crust in the NW area }\end{array}$ \\
\hline s11 & Discites p.p. & $\mathrm{L} / \mathrm{M}$ & $1.5-5$ & Greatest thickness in the central area, whereas thinnest deposits appear in the NW \\
\hline s12 & Discites p.p. & $\mathrm{L} / \mathrm{M}$ & $0.5-4$ & $\begin{array}{l}\text { Greatest thickness in the central area, whereas thinnest deposits appear in the NW. } \\
\text { Upper boundary is an erosive surface }\end{array}$ \\
\hline
\end{tabular}

Abbreviations: $\mathrm{L}=$ limestones; $\mathrm{M}=$ marl. 
Sequence 12 ( $\mathrm{s} 12)$ is formed by alternating marl and lime mudstone in the central area, whereas a succession of bioclastic wackestonepackstone appears in the NW sector of the area. The upper boundary is erosional. Thickness ranges from $0.5 \mathrm{~m}$ in the northwest area to $4 \mathrm{~m}$ in the central area.

In the Cameros area, sequences s2 to s12 (3rd to 4th-order) together constitute a single T-R facies cycle, with the transgressive hemicycle comprising the marl-dominated sequences $s 2$ to $s 8$, and the regressive portion the limestone-dominated sequences $s 9$ to s12.

\section{Isopachs maps}

Although generally condensed, the Aalenian record varies markedly both laterally and vertically in facies as well as in thickness, recording changes in accommodation space through time. Isopach maps have been drawn for every sequence (Fig. 9) and they clearly show differences in the sedimentary evolution of the four sectors distinguished in the study area (i.e. Demanda, San Leonardo, MaderoMoncayo and Cameros).

Isopachs referring to $\mathrm{S} 1$ and $\mathrm{s} 1$ (Aalensis Z. p.p.-Comptum Sz. p.p.) are shown in Fig. 9A. Two depocenters occur in the $S$ and NW subareas of the San Leonardo area, separated by a palaeohigh (Palacios de la Sierra section). The Madero-Moncayo area appears as a broad palaeohigh (Pinilla del Campo, Aldealpozo, Pozalmuro, Ciria and Borobia-I sections), whereas intermediate thicknesses occur in the Demanda area. The Cameros area shows a gradual increase in thickness toward the NW (Fig. 5D).

Fig. 9B shows that during the late Comptum Biochron, greatest sediment thicknesses are recorded in the E Madero-Moncayo area (Ciria, Borobia I and II sections), whereas the NW part of this area remains as a palaeohigh (Pinilla del Campo and Pozalmuro sections), the same as the central part of the San Leonardo area (Palacios de la Sierra and Vilviestre del Pinar sections) and some sectors of the Demanda area (Huerta de Arriba section). The previous SE-NW trend in the Cameros area switches to a WSW-ENE one.
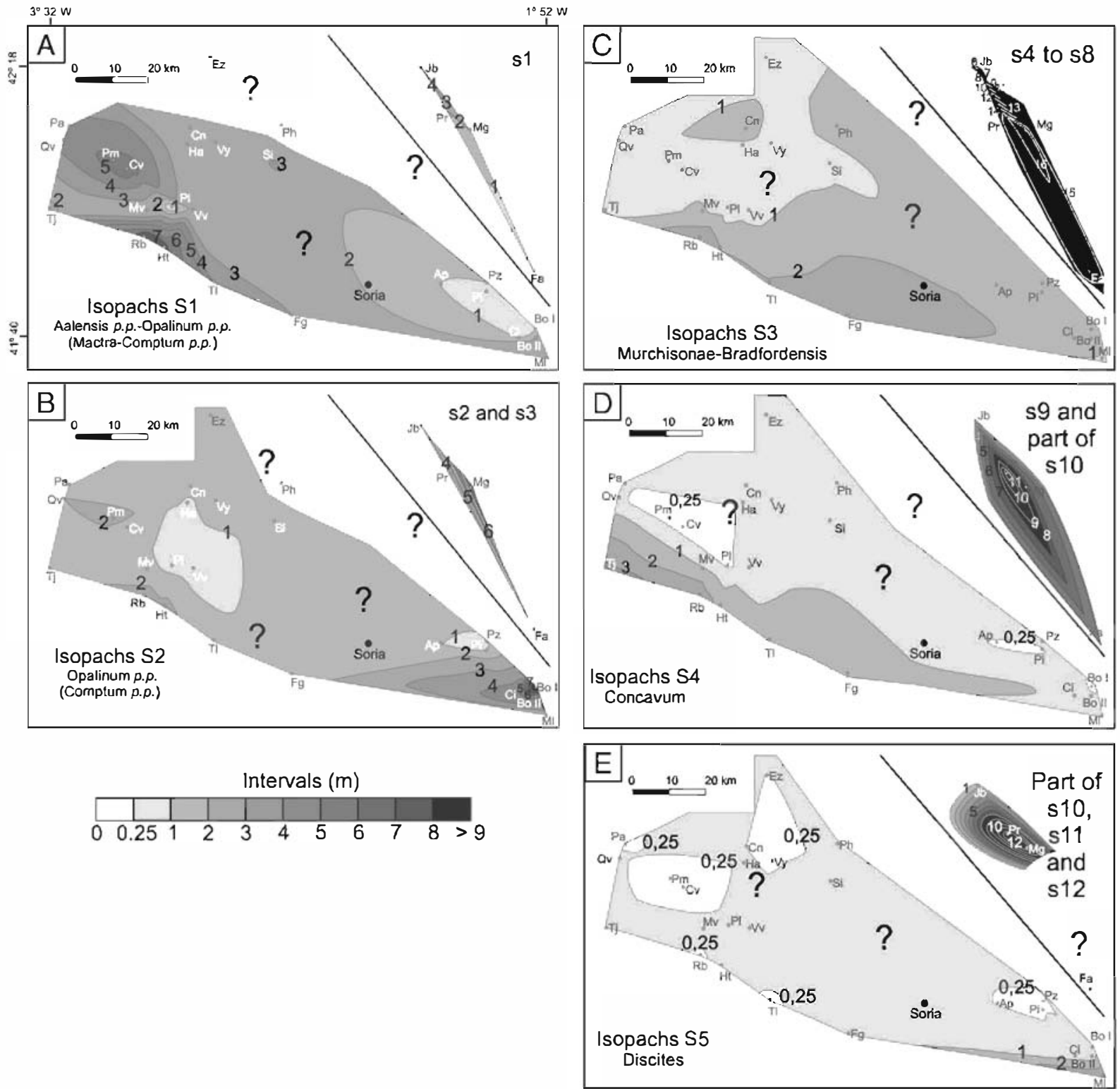

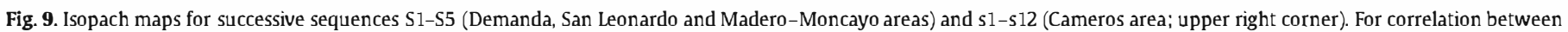
S- and s-sequences see Fig. 6. 
Fig. 9C (Murchisonae Z.-Bradfordensis Z.) shows how, higher up in the succession, sediment thicknesses become more uniform (1-2 $\mathrm{m}$ ) in the San Leonardo, Madero-Moncayo and Demanda areas, whereas the Cameros area differentially subsides (up to $15 \mathrm{~m}$ in the Muro de Aguas and Préjano sections).

Fig. 9D (Concavum Z.) shows that further up, broad homogenisation homogenization continues, but thickness drops to zero in the NW and central portions of the San Leonardo area (Piedrahita de Muñó, Castrovido and Palacios de la Sierra sections) and also in the western part of the Madero-Moncayo area (Aldealpozo and Pinilla del Campo sections). In the Cameros area, again, significantly thicker successions are deposited.

The isopach map referring to the youngest sequences (Fig. 9E; Discites Z.), shows near zero thicknesses all over the Demanda and San Leonardo areas (Ezcaray, Canales de la Sierra, Villavelayo, Paules de Lara, Piedrahita de Muñó, Castrovido and Talveila), as well as over most of the Madero-Moncayo area (Aldealpozo, Pinilla del Campo and Pozalmuro). However, up to $12 \mathrm{~m}$ are recorded for the same time interval in the central part of the Cameros area (Préjano and Muro de Aguas sections).

\section{Sediment accumulation data and tectono-sedimentary history}

In Fig. 10, the isopach patterns described in the foregoing section are combined with 'type sequences' characteristic of every region, in order to display the complex depositional architecture of the basin. 'Type sequences' summarize data provided in Figs. 7 and 8 (thickness and facies), as well as in Fig. 6 (regional unconformities).

Although thickness variations are small, vertical and lateral evolution of facies and sequence-bounding unconformities, never- theless, indicate differential subsidence and therewith synsedimentaryextensional tectonic activity. In fact, the above-described changes in isopach pattern over short time intervals (0.5-1 Ma) strongly suggest a control by active faults, such as the later inverted (Alpine orogeny) NW-SE trending Tablado and South Demanda faults (cf. Fig. 3), and possibly, a number of minor NE-SW trending faults that compartmentalized the sedimentation area. Facies homogenization since the Early Bajocian (Laeviuscula Z.) would seem to mark the end of fault activity.

Average sediment accumulation rates (present-day sequence thickness/time) for each of the 5 sequences distinguished in the Demanda, San Leonardo and Madero-Moncayo areas, and for the 12 sequences in the Cameros area are compared in Fig. 11.

As shown in Fig. 7, in the Demanda, San Leonardo and MaderoMoncayo areas, the Late Toarcian and Lower Aalenian sediments of S1 display quite monotonous lithology (limestone-marl alternation), which accumulated at an average rate of $1.49 \mathrm{~m} / \mathrm{Ma}$ (Fig. 11 A). During deposition of S2 (Early Aalenian, Comptum Biochron), a prominent change in facies is observed, with marl passing upward into bioclastic limestone, and/or Fe-bioclastic/Fe-oolitic limestone (Fig. 6). This change is paralleled by a drastic increase in net sedimentation rate (12 m/Ma; Fig. 11A). Thickness variation in S3 (Middle Aalenian) is minor (Fig. 10B,E), although facies development in the Demanda, San Leonardo and Madero-Moncayo areas differs significantly (Fig. 6). The average sedimentation rate dropped to $0.65 \mathrm{~m} / \mathrm{Ma}$ (Fig. $11 \mathrm{~A}$ ). In the Late Aalenian S4 (Fig. 10C), again, thicknesses vary only slightly among the different areas, although facies may change laterally (Fig. 6). Average sedimentation rate is similar to that estimated for the preceding sequence S3 $(0.70 \mathrm{~m} / \mathrm{Ma}$; Fig. $11 \mathrm{~A})$. Finally, a markedly homogeneous thickness distribution is generally observed in S5 (Early
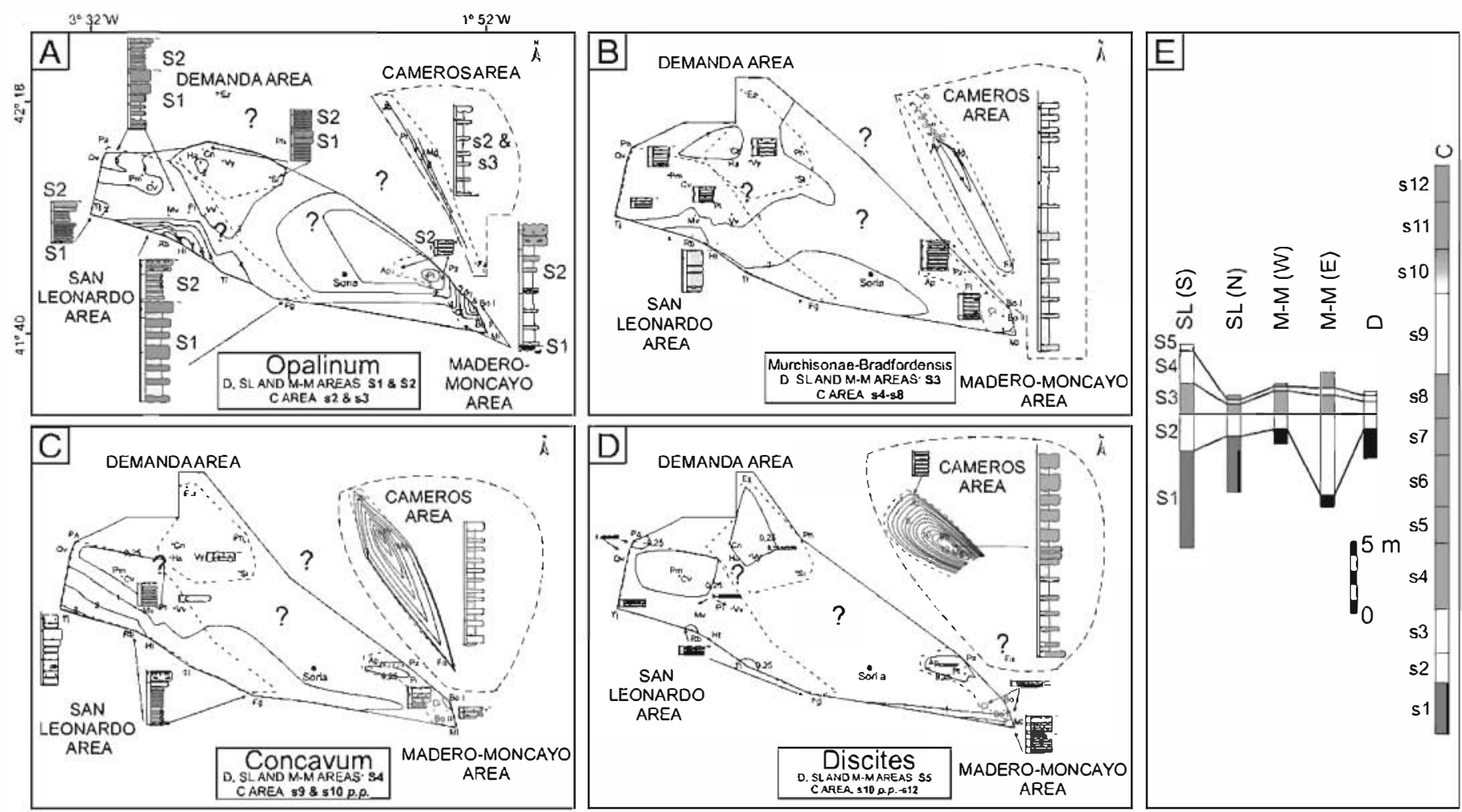

"Type sequences" Lithology
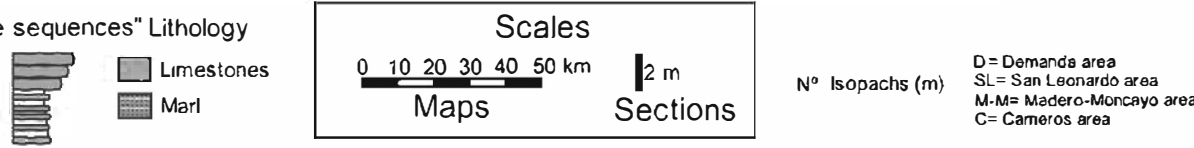

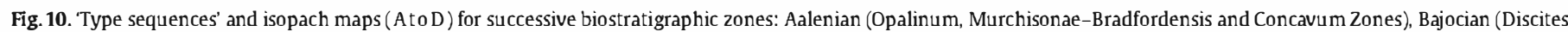
Zone); (E) Representation of thickness variations of successive sequences and total thicknesses measured in the different sectors of the study area. 

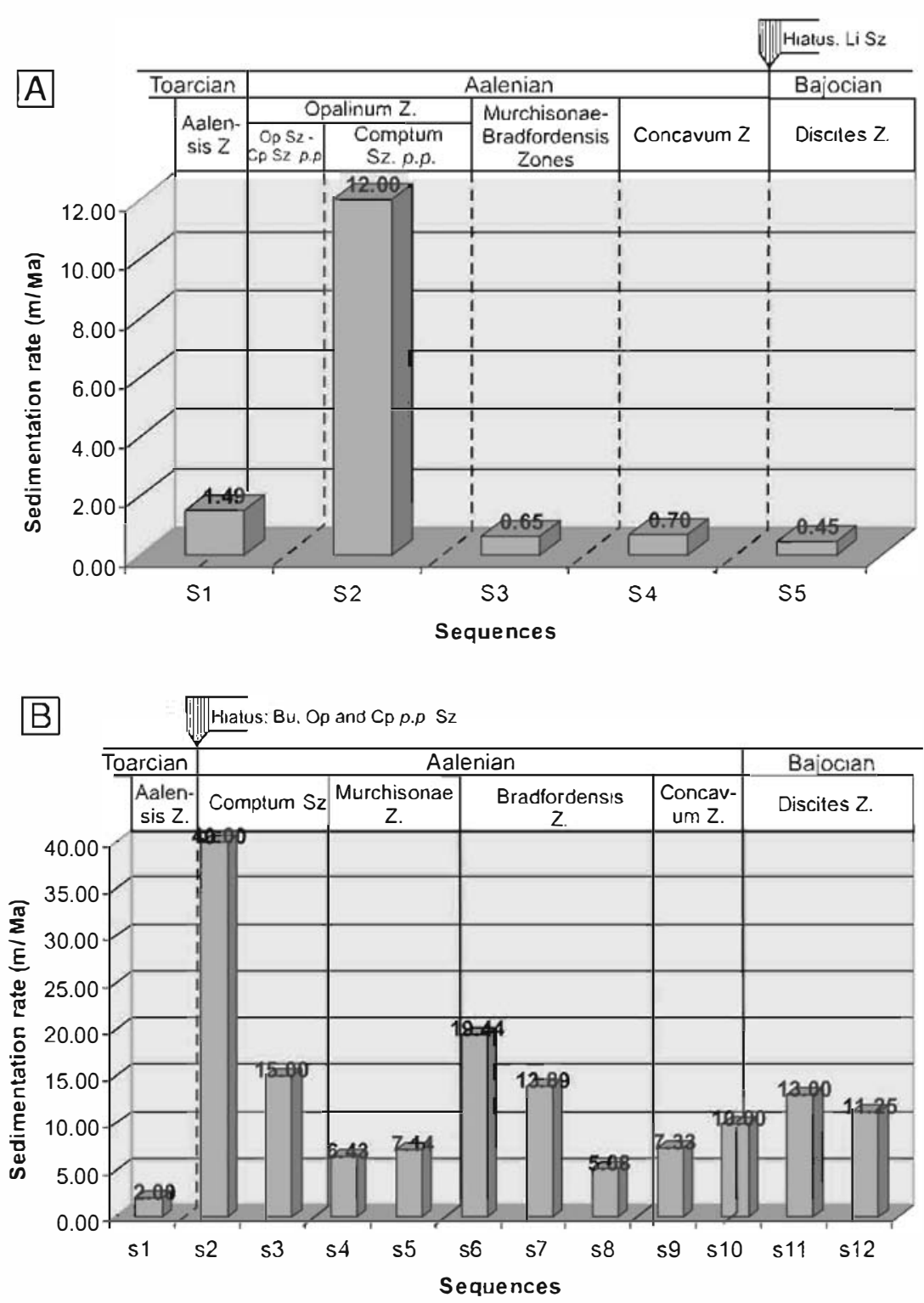

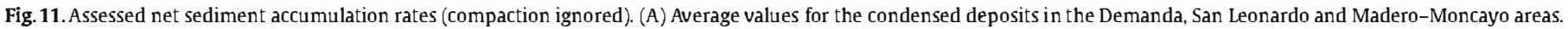

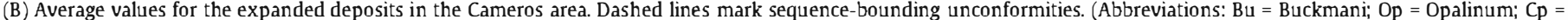
Comptum; Li = Limitatum; Z. = Zone; Sz. = Subzone).

Bajocian, Discites Biochron, Fig. 10D), where condensed limestones with ferruginous bioclasts/coated grains prevail in most sections. The sedimentation rate averages $0.45 \mathrm{~m} / \mathrm{Ma}$ (Fig. 11A).

In spite of the homogenous facies development, differences in net accumulation rates are also recorded among the sequences distinguished in the sections studied in the Cameros area (Fig. 11B). In this area, $s 1$ shows the lowest sedimentation rate $(2 \mathrm{~m} / \mathrm{Ma})$, although a major hiatus at the top of the sequence masks the real rate. This unconformity is coeval with the 'mid-Cimmerian' unconformity reported from several European basins by, for instance, Jacquin and Graciansky (1998a) and Graciansky and Jacquin (2003). s2, spanning the lower portion of Comptum Biochron, is the sequence with the highest sedimentation rate in the whole study area (40 m/Ma; Fig. 11B). In s3, comprising the rest of this same biochron, the average sedimentation rate drops to $15 \mathrm{~m} / \mathrm{Ma}$. Sequences s4 and s5 (Murchisonae Biochron) display even lower values (6.42 and $7.14 \mathrm{~m} / \mathrm{Ma}$ respectively). A notable change occurs in the Bradfordensis Zone, corresponding to sequences $s 6, s 7$ and $s 8$, where average sedimentation rates first increase and then progressively fall (s6: $19.44 \mathrm{~m} / \mathrm{Ma}$, s7: $13.0 \mathrm{~m} / \mathrm{Ma}$ and s8: $5.08 \mathrm{~m} / \mathrm{Ma}$ ). Sequences s9 and s10 (Concavum Biochron) accumulated at an average rate of $7.32 \mathrm{~m} / \mathrm{Ma}$ and $10.0 \mathrm{~m} /$ Ma respectively, marking a renewed increase. For s11 and s12, representing the Discites Biochron, assessed sedimentation rates are 13.0 and $11.25 \mathrm{~m} / \mathrm{Ma}$ respectively during this biochron.

In order to reveal changes in the rate of subsidence, and compare their timing, sediment 'accumulation history' diagrams (numerical geological age vs. uncorrected cumulative sediment thickness) have been produced for the different sectors distinguished in the study area (Fig. 12).

Fig. 12A compares the 'accumulation history' curve of the condensed deposits in the Demanda, San Leonardo and MaderoMoncayo areas (averaged values), with the one characterizing the more expanded record in the Cameros area. The curve representing the condensed successions displays a gentle slope from the Aalensis to the middle part of the Opalinum Biochron (175.1-174.6 Ma). A distinctive change in slope is recorded in the mid-upper part of the Comptum Biochron. Afterwards, thickness increases slowly until the earliest Bajocian. In the Cameros area, the increase in thickness from the Aalensis to the early Opalinum Biochron is similar to that in the areas with condensed sedimentation. The break in slope of the curve occurring in the middle-late portion of the Comptum Biochron is, 


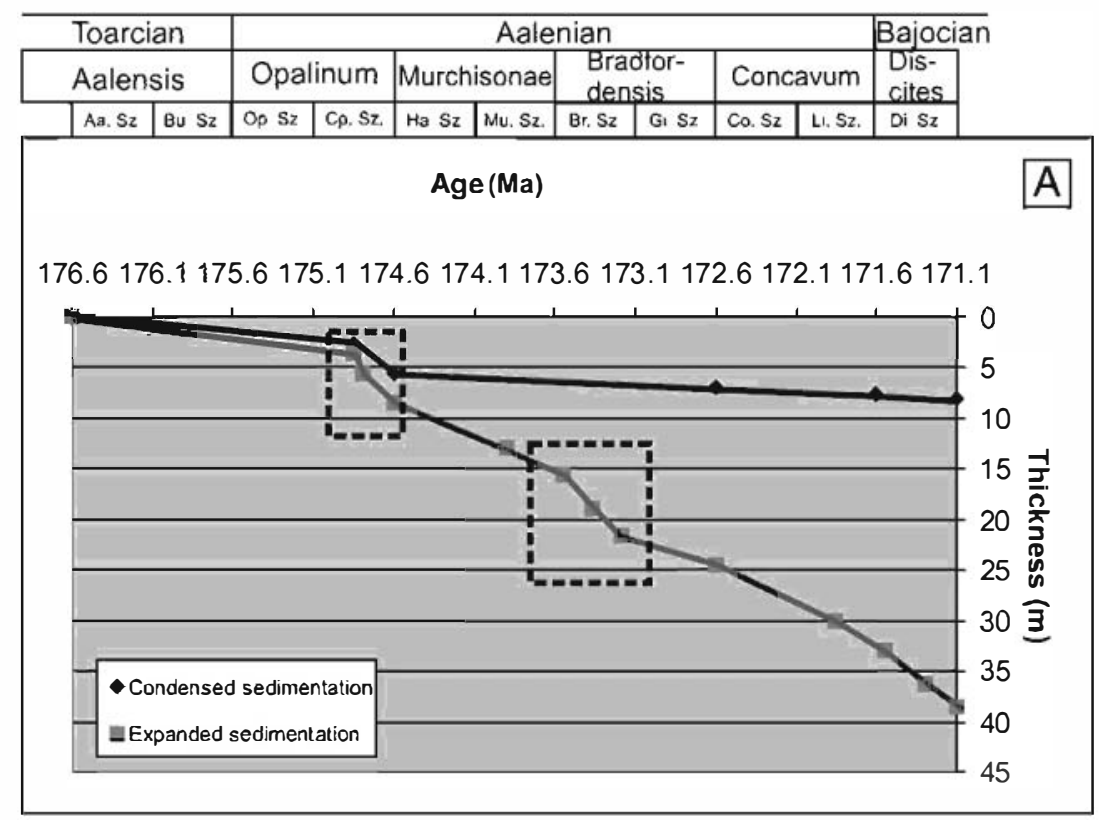

\begin{tabular}{|c|c|c|c|c|c|c|c|c|c|c|}
\hline \multirow{2}{*}{\multicolumn{2}{|c|}{$\begin{array}{l}\text { Toarcian } \\
\text { Aalensis }\end{array}$}} & \multicolumn{8}{|c|}{ Aalenian } & \multirow{3}{*}{$\begin{array}{l}\text { Bajociar } \\
\text { Dis- } \\
\text { cites } \\
\mathrm{Di} \mathrm{Sz}\end{array}$} \\
\hline & & Opa & inum & Murch & sonae & & $\begin{array}{l}\text { dor- } \\
\text { sis }\end{array}$ & Con & avum & \\
\hline $\mathrm{Aa}^{\mathrm{Sz}}$ & $\mathrm{Bu} \mathrm{Sz}$ & Op. Sz & $\mathrm{Cp} S \mathrm{Sz}$ & Ha. Sz. & Mu Sz & $8 \mathrm{r}, \mathrm{Sz}$ & $\mathrm{Gi} \mathrm{Sz}$ & $\mathrm{Co} . \mathrm{Sz}$ & L। Sz. & \\
\hline
\end{tabular}

Age (Ma)

$\begin{array}{llllllllllll}176.6 & 176.1 & 175.6 & 175.1 & 174.6 & 174.1 & 173.6 & 173.1 & 172.6 & 172.1 & 171.6 & 171.1\end{array}$

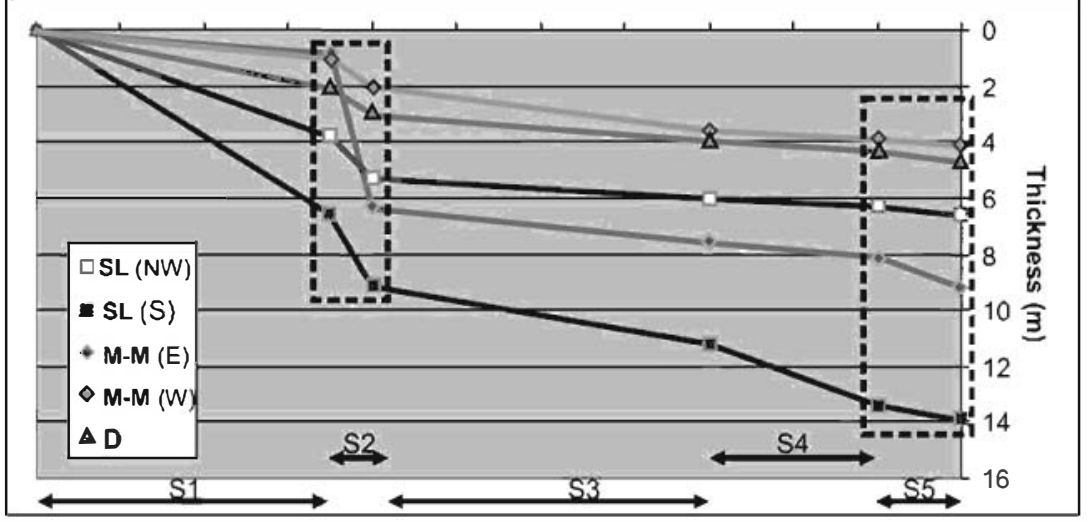

\begin{tabular}{|c|c|c|c|c|c|c|c|c|c|c|}
\hline \multirow{2}{*}{\multicolumn{2}{|c|}{$\begin{array}{l}\text { Toarcian } \\
\text { Aalensis }\end{array}$}} & \multicolumn{8}{|c|}{ Aalenian } & Bajoc \\
\hline & & Opa & inum & Murch & sonae & $\begin{array}{l}\text { Bra } \\
\text { der }\end{array}$ & $\begin{array}{l}\text { stor- } \\
\text { sis }\end{array}$ & Con & avum & $\begin{array}{l}\text { Dis- } \\
\text { cites }\end{array}$ \\
\hline $\mathrm{Aa} \mathrm{Sz}$ & Bu. Sz & Op. Sz & $C_{p} S_{2}$ & $\mathrm{Ha} \mathrm{Sz}$ & Mu Sz & $\mathrm{Br} \mathrm{Sz}$ & GI Sz & $\mathrm{CoSz}$ & LI Sz & $\mathrm{DiSz}$ \\
\hline
\end{tabular}

Age (Ma)

$\begin{array}{llllllllllll}176.6 & 176.1 & 175.6 & 175.1 & 174.6 & 174.1 & 173.6 & 173.1 & 172.6 & 172.1 & 171.6 & 171.1\end{array}$

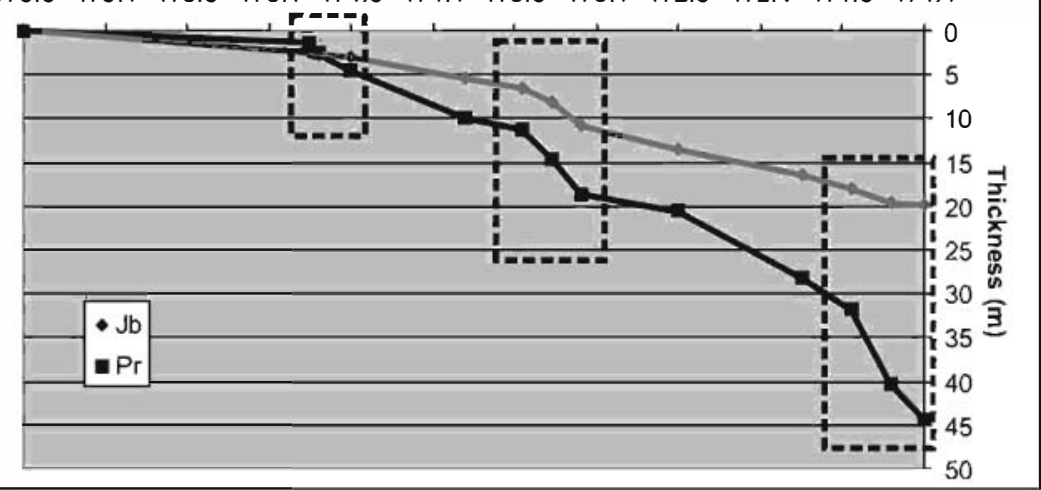




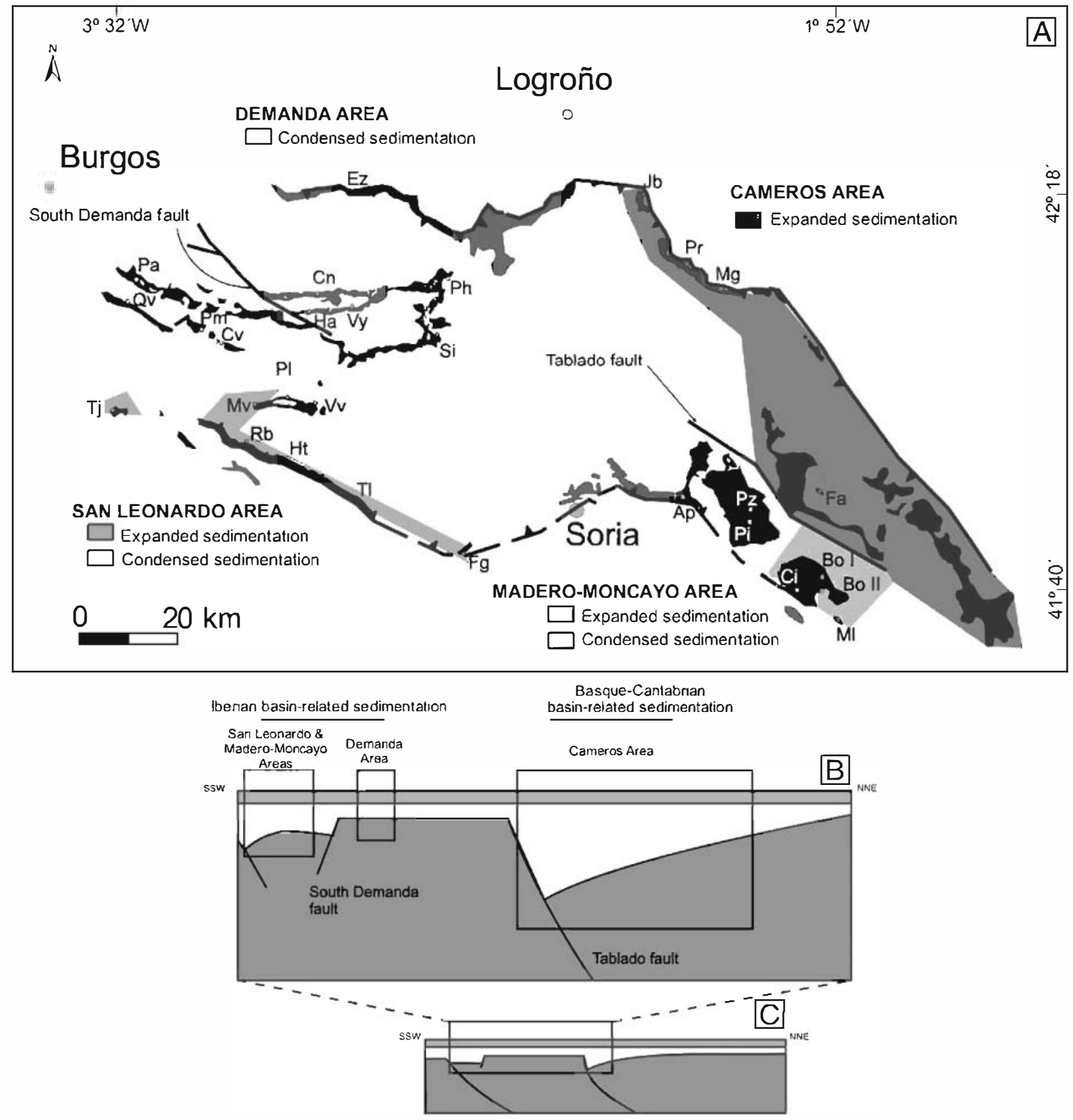

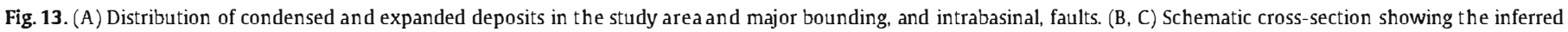
overall structural configuration.

however, more pronounced. Finally, from the beginning of the Murchisonae Biochron onward, the Cameros area shows a different trend, with an overall more pronounced gradient, and with a short steepening pulse occurring between Murchisonae and Bradfordensis Biochrons.

A separate representation of the 'accumulation histories' of the Demanda, San Leonardo and Madero-Moncayo areas is given in Fig. 12B. Apart from differences in overall thickness, there is a strikingly similar evolution in the three areas.

Fig. $12 \mathrm{C}$ shows the curves corresponding to the Jubera and Préjano sections in the Cameros area. The general trend is quite similar for both localities. Slope changes occur in both cases during the late portion of Comptum Biochron (175.1-174.6 Ma) and in early-middle Bradfordensis Biochron (173.6-173.1 Ma), but steepening of the curve during the Discites Biochron (171.6-171.1 Ma) is observed only in the Préjano section.

The inference thus is, from both the spatial and temporal evolution of sedimentation rates and the accumulation history diagrams described above, that synsedimentary tectonic activity was intermittent, with three distinctive pulses in the late-Early Aalenian, the late-Middle Aalenian (Bradfordensis Biochron) and in the earliest Bajocian

Fig. 13 includes a sketch map showing the distribution of areas with condensed and incomplete successions (deposited over a major fault-

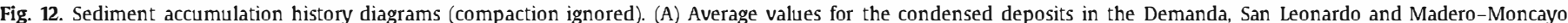

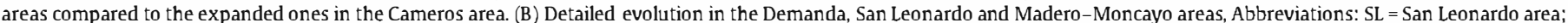

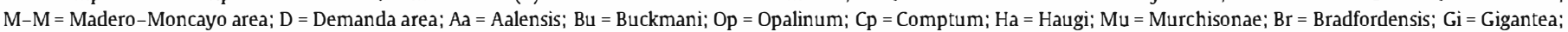
$\mathrm{Co}=$ Concavum; Li = Limitatum; Sz. = Subzone. (C) Detailed evolution of two sections in the Cameros area, Abbreviations: $\mathrm{Pr}=\mathrm{Préjano}$ section; Jb = Jubera section. 
bounded palaeohigh) and of areas characterized by an expanded sedimentary record (basinal setting), as well as a highly schematic SSE-NNW cross-section illustrating the inferred overall structural configuration in Early/Middle Jurassic time. The tectono-sedimentary evolution of the study area, represented in four successive steps, is shown in Fig. 14. In the same figure, we propose a broad subdivision into a south-southwestern 'Iberian Basin-related' and a north-northeastern 'Basque-Cantabrian Basin-related' sedimentation area (referred to in the following as IB domain and BCB domain respectively).

During the Aalensis and Opalinum Biochrons (Late Toarcian to early-Middle Aalenian boundary), sequences S1 and S2 accumulated in the IB domain, and $s 1-s 3$ to the NNE. The thickest record occurs in the southern portion of the IB domain (parts of the San Leonardo and Madero-Moncayo areas). However, even in these areas sedimentation was controlled by intermittent faulting, producing marked unconformities. Cumulative thickness of the coeval sequences $s 1-s 3$ in the BCB-domain, is comparable, but a major unconformity occurs at the base of $s 2$.

During the Murchisonae and Bradfordensis Biochrons (Middle Aalenian), S3 accumulated in IB domain, whereas 5 higher-order sequences $(s 4-s 8)$ were deposited in the BCB-domain. In the IB domain, condensed sequences with abundant iron-coated particles

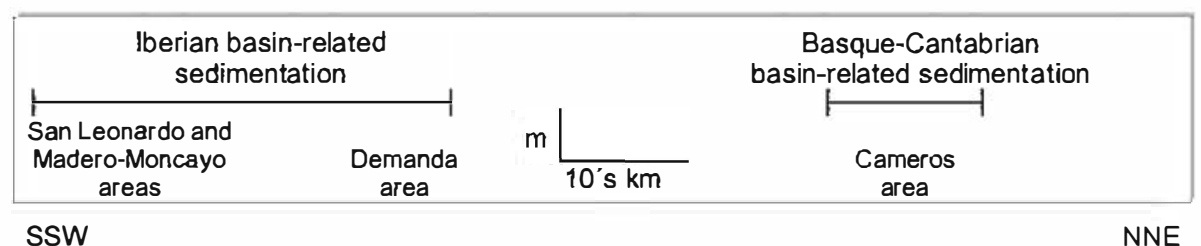

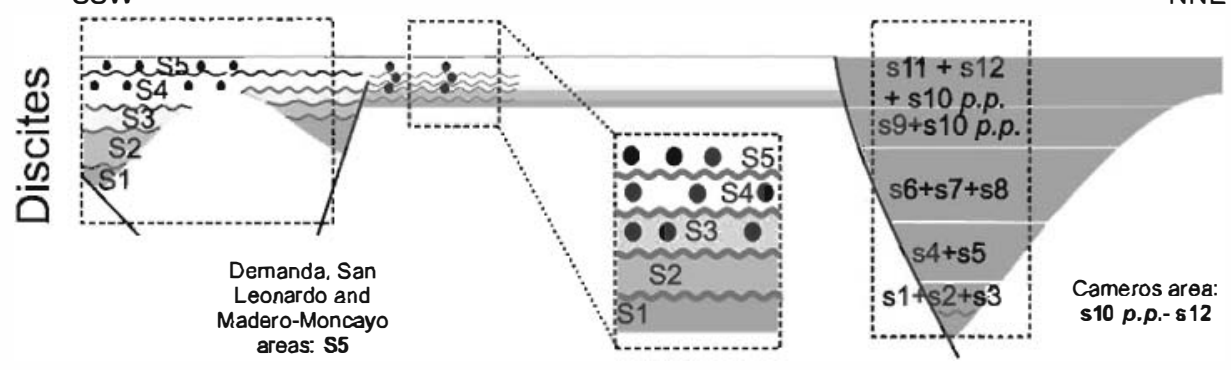

SSW

NNE
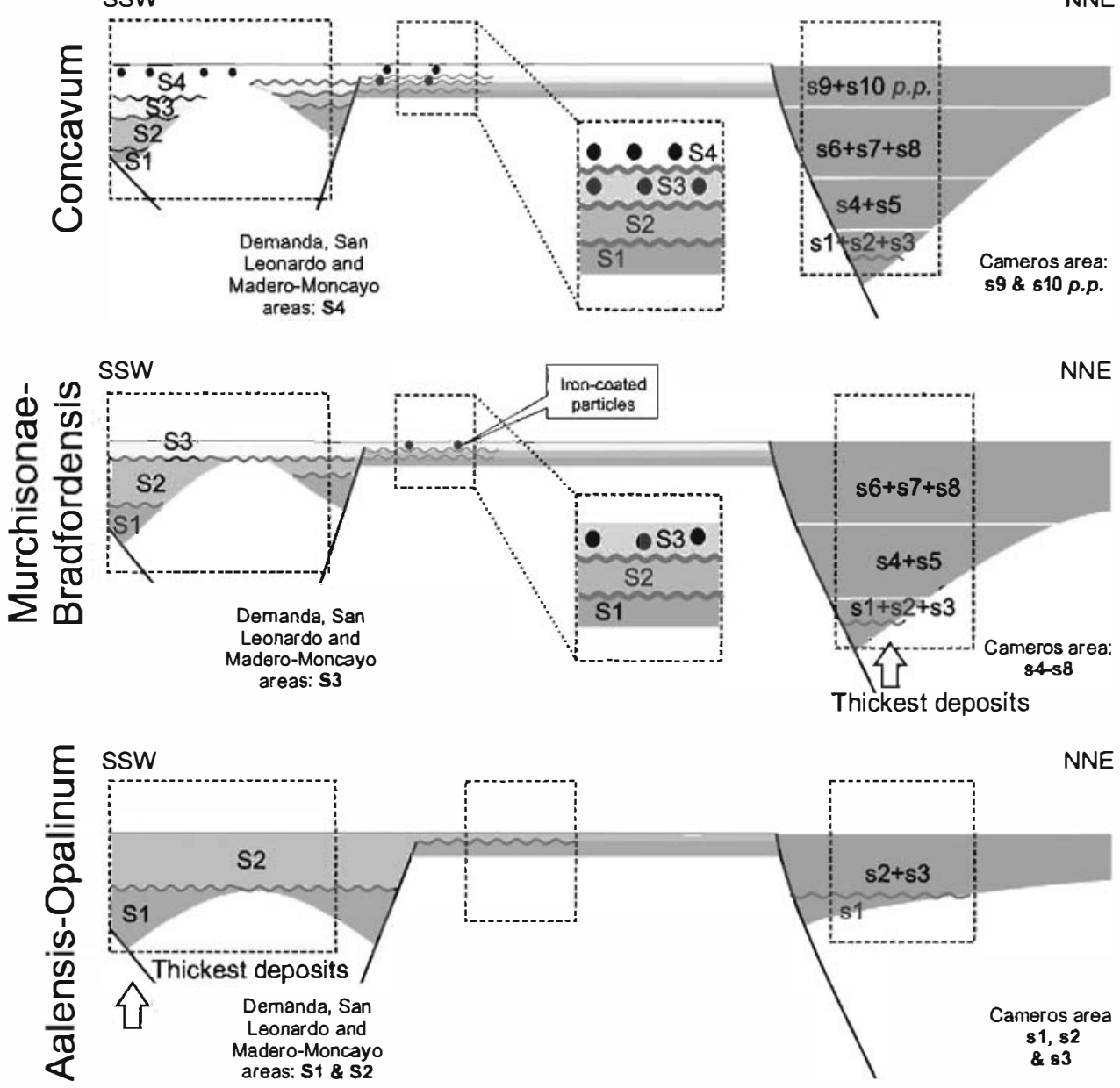

Fig. 14. Detailed evolutionary history of the study area. 
formed on top of elevated fault blocks (Demanda area) and continuous subsidence favoured an expanded sedimentation in the BCB-domain.

Within the Concavum Biochron (Late Aalenian), S4 developed in the IB domain, and s9 plus the lower part of s10 in the BCB-domain. Throughout the IB domain, the sedimentation rate dropped in most areas and favoured widespread occurrence of different types of ironcoated particles (García-Frank et al., 2006a). Also in the BCB-domain, sedimentation rates remarkably decreased with respect to the previous time interval.

The Discites Biochron (Early Bajocian) is represented in the IB domain by S5, whereas the upper part of s10, s11 and s12 accumulated in the BCB-domain. During this time interval maximum condensation occurred in the IB domain. In contrast, the BCB-domain records a renewed increase in accumulation rates. There is, however, a considerable difference between the northwest and central sectors of this domain, with condensed deposits characterizing the former and greater sediment thicknesses occurring in the latter. Lack of exposure in the Fuente de Ágreda area (Fig. 5) makes impossible to ascertain the evolution in the southeastern area (see Figs. 9E and 10D).

\section{The role of Aalenian magmatism: Central Iberia, $W$ and $S$ Iberian margins}

As evidenced by this study, in the NW Iberian Range the time interval from the Late Toarcian to the Early Bajocian was characterized by tectonic instability. Contemporaneous volcanism in sectors adjacent to the Iberian Basin has been attributed to crustal stretching. Several authors reported submarine volcanic activity

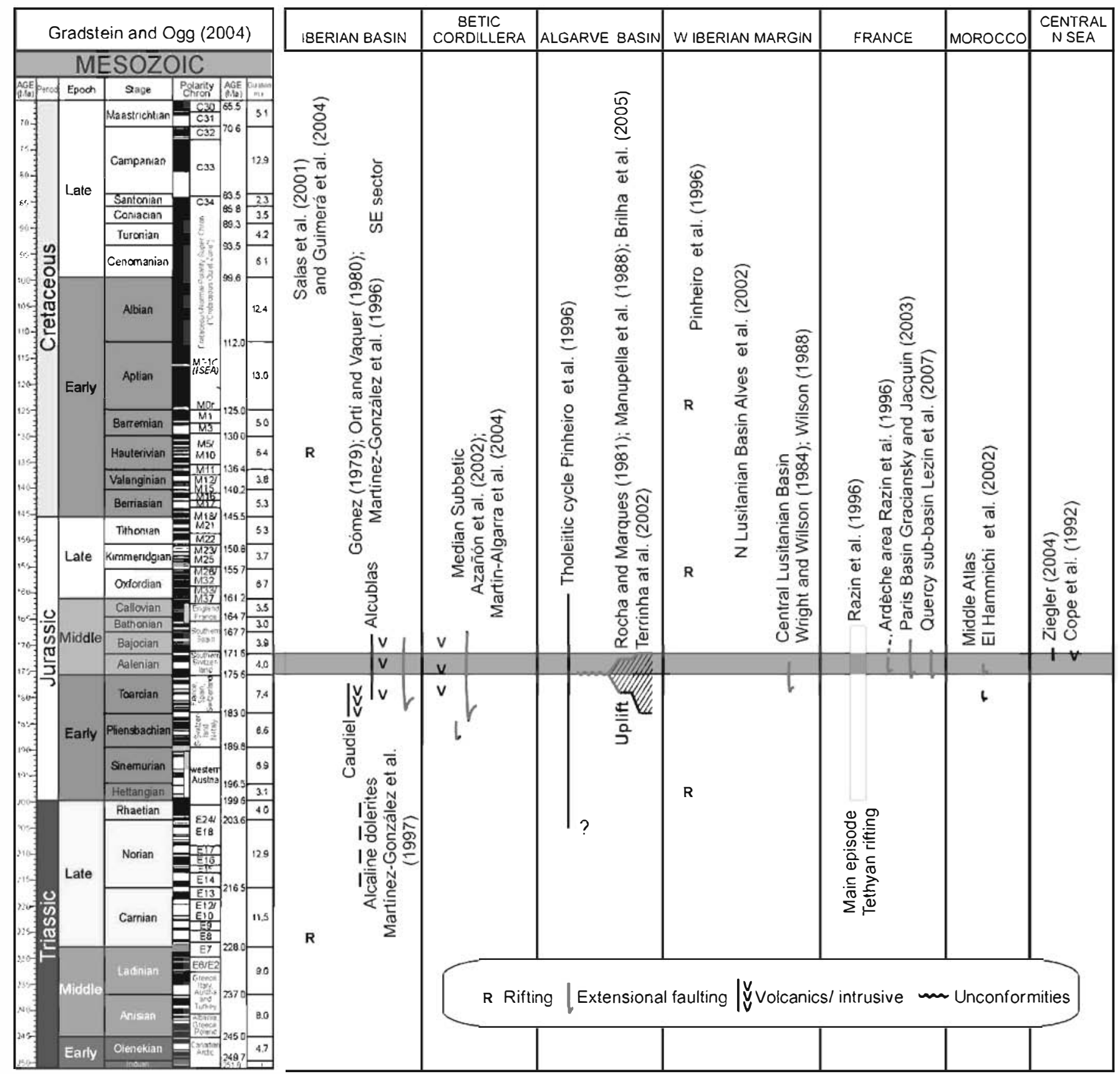

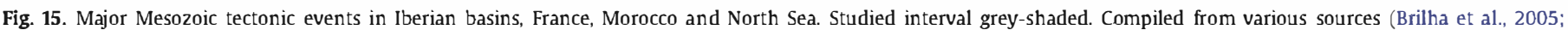
Manuppella et al., 1988). 
and the occurrence of pyroclastic deposits in the southeastern sector of the Iberian Range (Fig. 2B). These volcanic and volcaniclastic rocks occur interbedded with Toarcian, Aalenian and Bajocian sediments. The Late Pliensbachian-Toarcian Caudiel volcanic belt extended further south during Middle Jurassic times to give rise to the Alcublas pyroclastic belt, due to reactivation of large NW-SE faults (Gómez, 1979; Ortí and Vaquer, 1980). Basaltic and trachybasaltic emissions of Toarcian and Bajocian age were reported by Ortí and Vaquer (1980). Martínez González et al. (1996, 1997) placed the multiple episodes of alkaline volcanism (mainly volcaniclastic rocks, with subordinate basaltic sills) in the Jurassic thermal subsidence (postrift) stage, and suggested that this Pliensbachian-Bajocian volcanism was associated with cooling of a rift-related (pre-Hettangian) astenospheric plume.

Early-Middle Jurassic magmatic activity has also been reported from the Algarve area (S/W Iberia Margin, S of Nazaré Fault). A 205?$160 \mathrm{Ma}$ old tholeiitic cycle, associated with one of the three main rifting episodes recognized along the $W$ Iberian Margin, has been reported by Pinheiro et al. (1996, and references therein). In the Betic External Zones (Median Subbetic), sub-alkaline magmatic activity is documented by submarine volcanism (pillow lavas) and shallow subvolcanic intrusions, with a peak in activity in the Middle Jurassic, and presumably related to a SW-NE trending fault system (Martín-Algarra et al., 2004).

In the NW Iberian Range Jurassic magmatic rocks are absent, but in the studied stratigraphic interval (in particular, in the Upper AalenianLower Bajocian section) iron-coated particles commonly occur (García-Frank et al., 2006a). This iron enrichment has been interpreted by García-Frank (2007, and in prep.) as caused by exhalation from lowearth-element (REE) pattern of the iron-coated particles and that of coeval volcanic rocks in the Iberian Range.

Aalenian volcanism is not restricted to the margins of Iberia (Fig. 15). For instance, Ziegler (2004) reported that during the Middle Jurassic (Late Aalenian-Early Bajocian times), the Arctic seas became separated from both the Tethys and Central Atlantic owing to a large arch rising in the Central North Sea and the deposition of voluminous basalt, probably due to a short-lived mantle plume.

\section{Discussion}

\subsection{Role of extensional tectonics}

As already pointed out, there is general agreement that the prominent facies and thickness changes, as well as the widespread unconformities characterizing the Aalenian sedimentary record in Western Europe, are a consequence of synsedimentary extensional tectonics. This activity is thought to be related on the one hand to rifting in the Central Atlantic-Alpine Tethys system, and on the other, to volcanism and dome collapse in the North Sea Basin. Some authors refer to this episode as the 'Mid-Cimmerian events' (Jacquin and Graciansky, 1998a; Graciansky and Jacquin, 2003). Fig. 15 is a compilation of data from various sources, demonstrating the relevance of late late-Early and Middle Jurassic extensional tectonics on an overregional scale (e.g., Hallam, 2001; Ford and Golonka 2003; Geiger et al., 2004; Golonka, 2004; Ziegler, 2004; Geiger and Schweigert, 2006; Golonka, 2007, among many others).

In the Iberian Basin, reactivation of normal faults and compartmentalization of the previous carbonate platform during this extensional tectonic phase, has been postulated by Ureta (1985), Goy and Ureta (1990) and Fernández-López and Gomez (1990).

Local tectonic events have also been described from other regions for the same time interval. For instance, in the Basque-Cantabrian and Asturias basins, significant thickness variations, attributed to differential subsidence have been reported by Aurell et al. (2003). Moreover, a widespread unconformity around the Early-Middle Jurassic boundary has been considered by these authors as indicating renewed activity of normal faults (see also Quesada et al., 2005). Minor inconsistencies concerning the timing of regressive peaks, and associated stratigraphic gaps, in Iberian and other W-European basins have been explained in terms of local tectonics (Aurell et al., 2003).

According to Rasmussen et al. (1998), in the offshore Northern Lusitanian Basin, seismic data do not provide evidence of faultcontrolled subsidence during the Early and Middle Jurassic. However, Alves et al. (2002) argued that N-S to NW-SE trending faults were active throughout the Jurassic, and that seismic facies J20.b and J20.C (dated as Aalenian-Bajocian) were deposited during the late syn-rift and early post-rift stages in this area.

Evidence of fault-controlled subsidence has also been recognized in the onshore Northern and Central Lusitanian Basins, $\mathrm{N}$ and $\mathrm{S}$ of the Nazaré Fault Zone respectively. However, as stressed by several authors (e.g., Wright and Wilson, 1984; Wilson, 1988; Henriques, 1992, 1995; Azerêdo, 1998; Henriques, 2000), thickness and facies development of the early early-Middle Jurassic deposits from both basins are different. In the N Lusitanian Basin, Aalenian deposits are generally well developed and show a marked E-W facies differentiation, presumably controlled by the $\mathrm{N}-\mathrm{S}$ trending Arunca-Montemor 'fracture axis' (Henriques, 1992, 1995). Relying on the data provided by Henriques (1992), it appears, however, that the $\mathrm{N}$ and $\mathrm{S}$ portions of the N Lusitanian Basin notably differ in terms of the detailed pattern of sediment accumulation (Comptum-Concavum Biochrons), probably as a result of tilting of the sedimentation area.

Changes in palaeogeography can be detected as well in the Central Lusitanian Basin. In the easternmost sector of the Central Lusitanian Basin (Tomar sector) sediments attributed to a proximal inner-ramp setting occur (Azerêdo, 1998). An expanded rhythmic marl-limestone alternation characterizes the central part of the basin (Zambujal de Alcaria section; Henriques, 2000). Duarte (1997) inferred a homoclinal ramp setting for the Late Liassic. Ramp dip was towards the west, and was apparently controlled by $\mathrm{N}-\mathrm{S}$ and NE-SW trending normal faults. By contrast, at the $\mathrm{W}$ border of the Central Lusitanian Basin (Peniche sector), the Toarcian-Aalenian succession is represented by thick terrigenous turbiditic sediments and resedimented oolitic limestones, supplied from the ad jacent uplifted Berlengas-Farilhoes horst (Wright and Wilson, 1984; Wilson, 1988).

In the Algarve Basin, an unconf ormity marks the Toarcian-Aalenian transition, with a hiatus that, according to Rocha and Marques (1981), spans from the early Toarcian (Serpentinus Biochron) to Aalenian p.p. However, Terrinha et al. (2002), suggest a longer duration for this hiatus (early Toarcian to Aalenian/Bajocian boundary).

Fault-controlled facies changes and migration of depocenters, have been documented in several French basins in the studied time interval. In the Ardèche area, several pulses of extensional tectonic activity have been detected around the late Toarcian-Aalenian transition (Razin et al., 1996). The activity of extensional faults in the Paris Basin is marked by stratigraphic gaps and condensed layers from the latest Toarcian to the earliest Bajocian (de Graciansky and Jacquin, 2003). According to Lezin et al. (2007), in the Aquitaine Basin (Quercy subbasin) the depositional regime changed during the Middle Aalenian, as a consequence of synsedimentary block faulting.

Increased tectonic activity has also been reported from the western Middle Atlas in Morocco, during Toarcian-Aalenian interval, causing fragmentation of the sedimentation area into several sub-basins (El Hammichi et al., 2002).

\subsection{Eustatic signals}

This widely recorded phase of tectonic activity, is coeval with the early early-Middle Jurassic overall regressive trend recognized in most European basins (regressive phase of 1st-order 'Ligurian Cycle; e.g. de Graciansky et al., 1998; Jacquin and Graciansky, 1998a,b). Maximum progradation occurred during the Late Aalenian or earliest Bajocian, depending on subsidence and sedimentary supply (Jacquin and 
Cycles

\begin{tabular}{|c|c|c|c|c|c|c|c|c|c|}
\hline $\begin{array}{c}\text { Lusitanıan } \\
\text { Basın }\end{array}$ & Basque- & $\begin{array}{l}\text { Cantabrian } \\
\text { asin }\end{array}$ & & Iberian & Basin & & $\begin{array}{l}\text { NW } \\
\text { Europe }\end{array}$ & & \\
\hline \multirow{3}{*}{$\begin{array}{l}\text { Duarte et al } \\
\text { (2001) }\end{array}$} & \multirow{3}{*}{$\begin{array}{l}\text { Aurell et al. } \\
(2003) \\
\text { 2nd Order }\end{array}$} & \multirow{3}{*}{$\begin{array}{c}\text { Quesada et al } \\
\text { (2005) } \\
\text { 2nd Order }\end{array}$} & \multirow{3}{*}{$\begin{array}{c}\text { Aurell et al. } \\
\text { (2003) } \\
\text { 2nd Order }\end{array}$} & \multirow{3}{*}{$\begin{array}{c}\text { 2nd Order } 3 r d \text { Order } \\
\text { 6-12 Ma } 1.5 \mathrm{Ma} \\
\text { Gomez and Goy (2005) } \\
\text { Gomez and Fernández- } \\
\text { Lopez (2004) }\end{array}$} & \multicolumn{2}{|c|}{$\begin{array}{ccc}\text { 2nd Order } & \text { This work } \begin{array}{c}\text { 3rd Order } \\
0.5-3 \mathrm{Ma}\end{array} \\
\end{array}$} & \multirow{3}{*}{$\begin{array}{c}\text { Jacquin el al. } \\
\text { (1998) } \\
\text { 3ro Order }\end{array}$} & \multirow{3}{*}{\multicolumn{2}{|c|}{$\begin{array}{l}\text { Geochronological } \\
\text { Divisions }\end{array}$}} \\
\hline & & & & & \multirow{2}{*}{ Cameros area } & \multirow{2}{*}{$\begin{array}{c}\text { Demanda. San } \\
\text { Leonardo and } \\
\text { Madero-Moncayo } \\
\text { areas }\end{array}$} & & & \\
\hline & & & & & & & & & \\
\hline & & & & & & & \multirow{2}{*}{ Bj1 } & \multirow{2}{*}{ B } & Laeviuscula \\
\hline & & & & & & & & & Discites \\
\hline & & & & & & & Aa2 & \multirow{3}{*}{$\frac{\frac{c}{\frac{\pi}{\pi}}}{\frac{\mathrm{d}}{\mathrm{d}}}$} & Concavum \\
\hline & & & & & & & $A=1$ & & \begin{tabular}{|l} 
Murchisonae \\
\end{tabular} \\
\hline & & & & & & & & & Opalinum \\
\hline & & & & & & & 101 & $\bar{T}$ & Aalensis \\
\hline
\end{tabular}

Fig. 16. T-R cycle subdivisions proposed in previous studies compared to subdivision proposed in this study.

Graciansky, 1998a). A widespread unconformity separates the 'Ligurian Cycle' from the subsequent 1st-order 'North Sea Cycle' (Jacquin and Graciansky, 1998a; Jacquin et al., 1998). In the North Sea Basin, this unconformity has been called by Underhill and Partington (1994) 'midCimmerian' unconformity, and is represented by a significant regional truncation. This unconformity also marks the boundary between two successive T-R 2nd-order cycles. Due to poor biostratigraphic constraints, there is however, no general agreement concerning its precise age (e.g. Haq et al., 1988; Razin et al., 1996; Jaquin et al., 1998; Jacquinand de Graciansky, 1998a,b; de Graciansky and Jacquin, 2003).

The transgressive-regressive (T-R) cycles we here define in NW Iberian Basin for the studied time interval are correlated in Fig. 16 with the composite 3rd-order cycles established for the NW European basins (lacquin et al., 1998), and cycle subdivisions (mostly 2nd-order cycles) proposed by other authors (e.g. Duarte et al., 2001; Aurell et al., 2003; Gómez and Femández-López, 2004; Gómez and Goy, 2005; Quesada et al., 2005).

The unconformities bounding the 3rd-order cycles that we have identified in the IB domain of the study area match in general with T-R cycle boundaries defined in NW Europe, and so do the boundaries of our 2nd-order T-R facies cycle in BCB-domain. Exceptions are the boundaries of sequences S2 and S3 in the IB domain. We interpret this misfit as an effect of local tectonics.

Unconformity U1, between S1 and S2 (intra-Comptum Sz.), has also been identified in the Asturias and in Basque-Cantabrian basins (Aurell et al., 2003), but Goy and Ureta (1994) remarked that it can only be identified in marginal areas of these basins. Azerêdo et al. (2003) stated that in the Lusitanian Basin in the Toarcian-Aalenian boundary interval depositional sequences are bounded by important unconformities. Duarte et al. (2001), relying on available biostratigraphic data, suggested for unconformity 'DA1' an intra-Comptum age, coinciding with our timing of U1. The second unconformity (U2), at the top of S2 (between Opalinum and Murchisonae Zones), coincides with an unconformity identified in the Betic Ranges and over wide areas of the SE Iberian Range (e.g. O'Dogherty et al., 2000; Gómez and Fernández-López, 2006). The boundary between 'megasequences' ' $E$ ' and ' $F$ ' defined by Soares and Duarte (1997) in the Lusitanian Basin, corresponds to unconformity 'D6', situated at the top of Opalinum Zone, where Duarte and Henriques (2001) indicated sedimentary condensation. Henriques $(1992,1995)$ placed this unconformity at the base of cycle 'ZA 1' of Haq et al. (1988). The third unconformity (U3), at the top of S3 and (between the Bradfordensis and Concavum Zones) correlates with an unconformity cited from various European localities (Jacquin and de Graciansky, 1998a). Quesada et al. (2005) reported a contemporaneous unconformity in the Basque-Cantabrian Basin, but detailed biostratigraphic data demonstrated that it represents actually an intra-Concavum hiatus (Goy and Ureta, 1994). The forth unconformity (U4), at the top of S4 (between Concavum and Discites Zones), is equivalent to that described at the western margin of the Subalpine Basin by Razin et al. (1996) and in the Quercy Basin by Lezin et al. (2007). The last one, U5, at the top of S5 (between Discites and Laeviuscula Zones), is equivalent to an unconformity recognized in the Paris Basin by de Graciansky and Jacquin (2003).

As described above, there are twelve 3rd- to 4th-order stratigraphic sequences in the $\mathrm{BCB}$-domain, but only two sequence boundaries are marked by major unconformities. The unconformity between $s 1 / s 2$ (intra-Comptum Sz.) correlates with U1 in the IB domain, and the one at the top of $\mathrm{s} 12$ (between the Discites and Laeviuscula Zones), withU5. Unconformities U2, U3 and U4 have no counterparts in the BCBdomain. A close similarity in sequence development is observed between the IB domain and $\mathrm{BCB}$ domain before the major unconformity U1, but a markedly different sequential organization developed after the Early Aalenian onwards (post post-U1).

According to the data exposed in this chapter, we think that transgressive and regressive trends recorded in the stratigraphy during the studied time interval were controlled principally by regional tectonics (evolution of the Atlantic-Alpine Tethys system), rather than by eustatic changes of sea level. This is further supported by the generally accepted view that glacio-eustasy cannot be invoked as an explanation for sea-level changes in Early and Middle Jurassic time.

\section{Conclusions}

A stable epeiric platform characterized the NW part of the Iberian Basin until the Early Aalenian. After unconformity U1, dated as Late Comptum in age, a differentiation in two major facies domains occurred in the study area (IB domain, including the Demanda, San Leonardo and Madero-Moncayo areas vs. BCB-domain, represented by the Cameros area), most likely caused by active extensional faulting. In particular, prominent facies and thickness changes, the widespread occurrence of unconformities, as well as the sequential organization (transgressive and regressive trends) characterizing the Aalenianlowermost Bajocian sedimentary record favour a tectonic, rather than eustatic control.

Two main episodes of faulting have been recognized in the studied time interval, that affected both the IB- and the BCB-domain. These occurred in the latest Comptum (late-Early Aalenian) and in Discites (earliest Bajocian) time respectively. A third pulse, in the Bradfordensis Biochron (late-Middle Aalenian) has been detected only in the BCB-domain. The intra-Comptum tectonic pulse is recorded in other basins of Iberia (Basque-Cantabrian, Asturias basins and North Lusitanian Basin), and there appears to be a link with Middle Jurassic magmatic activity in the SE Iberian Basin, the Betic External Zones (Median Subbetic), and the Algarve Basin. Extensional faulting in the NW Iberian Basin could have initiated hydrothermal processes and exhalative events, documented by repeated intercalations of iron-rich beds in the Upper ToarcianLower Bajocian section.

Synsedimentary faulting in this period, and associated widespread unconformities, have also been described from several NW European 
basins, where they have been referred to as the 'mid-Cimmerian event', and interpreted as the combined effect of late rifting in the Alpine Tethys realm and incipient rifting in the North Sea region.

This study provides precise age constrains concerning the chronology of the main tectonic pulses recorded in NW Iberia for the Upper Toarcian-Lower Bajocian interval, that may help to resolve uncertainties in the stratigraphy of other W European basins during this time interval.

In conclusion, it appears that a combination of detailed stratigraphic and precise biostratigraphic work can reveal details on the accumulation history, and the underling controls (tectonics, sea-level changes...), even in the case of condensed deposits, which generally are considered to be of difficult interpretation. Analyses of the same level of detail yield significant results in other cases where condensed facies dominate the stratigraphic record.

\section{Acknowledgements}

We appreciate the interesting comments provided by Dr. M. M. Kimberley. We thank the suggestions and constructive comments provided by T. Alves and an anonymous referee that greatly improved earlier versions of this manuscript. This work was funded by projects CGL2005-04574 and BTE 2001-026 of the Spanish Ministerio de Educación y Ciencia and by project 910431 of the UCM-CAM.

\section{Appendix A. Location of the sections studied in this work}

\begin{tabular}{|c|c|c|c|}
\hline & Section & Latitude & Longitude \\
\hline \multirow[t]{6}{*}{ Demanda area } & Ezcaray (Ez) & $42^{\circ} 19^{\prime} 6.15^{n} \mathrm{~N}$ & $2^{\circ} 59^{\prime} 23.75^{\prime \prime} \mathrm{W}$ \\
\hline & Canales de la Sierra $(\mathrm{Cn})$ & $42^{\circ} 8^{\prime} 58.11^{\prime \prime} \mathrm{N}$ & $3^{\circ} 3^{\prime} 26.43^{\prime \prime} \mathrm{W}$ \\
\hline & Huerta de Arriba (Ha) & $42^{\circ} 6^{\prime} 57.72^{\prime \prime} \mathrm{N}$ & $3^{\circ} 4^{\prime} 38.78^{\prime \prime} \mathrm{W}$ \\
\hline & Villavelayo (Vy) & $42^{\circ} 3^{\prime} 10.26^{\prime \prime} \mathrm{N}$ & $2^{\circ} 59^{\prime} 19.67^{\prime \prime} \mathrm{W}$ \\
\hline & Santa Inés (Si) & $42^{\circ} 4^{\prime} 11.46^{\prime \prime} \mathrm{N}$ & $2^{\circ} 46^{\prime} 47.51^{\prime \prime} \mathrm{W}$ \\
\hline & Peñahincada $(\mathrm{Ph})$ & $42^{\circ} 10^{\prime} 2.42^{\prime \prime} \mathrm{N}$ & $2^{\circ} 45^{\prime} 35.74^{\prime \prime} \mathrm{W}$ \\
\hline \multirow[t]{12}{*}{ San Leonardo area } & Paules de Lara $(\mathrm{Pa})$ & $42^{\circ} 9^{\prime} 33.54^{\prime \prime} \mathrm{N}$ & $3^{\circ \circ} 28^{\prime} 1.93^{\prime \prime} \mathrm{W}$ \\
\hline & Quintanilla de las Viñas (Qv) & $42^{\circ} 7^{\prime} 25.07^{\prime \prime} \mathrm{N}$ & $3^{\circ} 28^{\prime} 53.25^{\prime \prime} \mathrm{W}$ \\
\hline & Piedrahita de Muñó (Pm) & $42^{\circ} 4^{\prime} 40.17^{\prime \prime} \mathrm{N}$ & $3^{\circ} 18^{\prime} 42.2^{\prime \prime} \mathrm{W}$ \\
\hline & Castrovido (Cv) & $42^{\circ} 3^{\prime} 18.07^{\prime \prime} \mathrm{N}$ & $3^{\circ} 16^{\prime} 23.37^{\prime \prime} \mathrm{W}$ \\
\hline & Moncalvillo (Mv) & $41^{\circ} 56^{\prime} 59.69^{\prime \prime} \mathrm{N}$ & $3^{\circ} 11^{\prime} 58.9^{\prime \prime} \mathrm{W}$ \\
\hline & Palacios de la Sierra (PI) & $41^{\circ} 57^{\prime} 25.33^{\prime \prime} \mathrm{N}$ & $3^{\circ} 6^{\prime} 53.69^{\prime \prime} \mathrm{W}$ \\
\hline & Vilviestre del Pinar (Vv) & $41^{\circ} 56^{\prime} 51.7^{\prime \prime} \mathrm{N}$ & $3^{\circ} 4^{\prime} 34.09^{\prime \prime} \mathrm{W}$ \\
\hline & Tejada (Tj) & $41^{\circ} 57^{\prime} 1.76^{\prime \prime} \mathrm{N}$ & $3^{\circ} 31^{\prime} 36.68^{\prime \prime} \mathrm{W}$ \\
\hline & Rabanera (Rb) & $41^{\circ} 53^{\prime} 1.35^{\prime \prime} \mathrm{N}$ & $3^{\circ} 13^{\prime} 37.59^{\prime \prime} \mathrm{W}$ \\
\hline & Hontoria $(\mathrm{Ht})$ & $41^{\circ} 51^{\prime} 30.22^{\prime \prime} \mathrm{N}$ & $3^{\circ} 9^{\prime} 19.04^{\prime \prime} \mathrm{W}$ \\
\hline & Talveila (T1) & $41^{\circ} 40^{\prime} 38.31^{\prime \prime} \mathrm{N}$ & $2^{\circ} 58^{\prime} 4.73^{\prime \prime} \mathrm{W}$ \\
\hline & Las Fraguas (Fg) & $41^{\circ} 40^{\prime} 53.15^{\prime \prime} \mathrm{N}$ & $2^{\circ} 44^{\prime} 9.44^{\prime \prime} \mathrm{W}$ \\
\hline \multirow{7}{*}{$\begin{array}{l}\text { Madero-Moncayo } \\
\text { area }\end{array}$} & Aldealpozo (Ap) & $41^{\circ} 46^{\prime} 32.61^{\prime \prime} \mathrm{N}$ & $2^{\circ} 14^{\prime} 7.14^{\prime \prime} \mathrm{W}$ \\
\hline & Pozalmuro (Pm) & $41^{\circ} 46^{\prime} 17.52^{\prime \prime} \mathrm{N}$ & $2^{\circ} 4^{\prime} 29.41^{\prime \prime} \mathrm{W}$ \\
\hline & Pinilla del Campo (Pi) & $41^{\circ} 46^{\prime} 10.35^{\prime \prime} \mathrm{N}$ & $2^{\circ} 4^{\prime} 32.82^{\prime \prime} \mathrm{W}$ \\
\hline & Ciria $(\mathrm{Ci})$ & $41^{\circ} 37^{\prime} 27.62^{\prime \prime} \mathrm{N}$ & $1^{\circ} 58^{\prime} 12.44^{\prime \prime} \mathrm{W}$ \\
\hline & Borobia I (Bo-I) & $41^{\circ} 38^{\prime} 53.43^{\prime \prime} \mathrm{N}$ & $1^{\circ} 54^{\prime} 46.26^{\prime \prime} \mathrm{W}$ \\
\hline & Borobia II (Bo-II) & $41^{\circ} 37^{\prime} 29.75^{\prime \prime} \mathrm{N}$ & $1^{\circ} 56^{\prime} 24.03^{\prime \prime} \mathrm{W}$ \\
\hline & Malanquilla (Ml) & $41^{\circ} 35^{\prime} 40.44^{\prime \prime} \mathrm{N}$ & $1^{\circ} 52^{\prime} 5.76^{\prime \prime} \mathrm{W}$ \\
\hline \multirow[t]{4}{*}{ Cameros area } & Fuentes de Ágreda (Fa) & $41^{\circ} 48^{\prime} 16.6^{\prime \prime} \mathrm{N}$ & $1^{\circ} 54^{\prime} 39.18^{\prime \prime} \mathrm{W}$ \\
\hline & Muro de Aguas (Mg) & $42^{\circ} 8^{\prime} 25.52^{\prime \prime} \mathrm{N}$ & $2^{\circ} 6^{\prime} 26.24^{\prime \prime} \mathrm{W}$ \\
\hline & Préjano (Pr) & $42^{\circ} 10^{\prime} 36.15^{\prime \prime} \mathrm{N}$ & $2^{\circ} 11^{\prime} 19.88^{\prime \prime} \mathrm{W}$ \\
\hline & Jubera (Jb) & $42^{\circ} 17^{\prime} 50.75^{\prime \prime} \mathrm{N}$ & $2^{\circ} 17^{\prime} 35.38^{\prime \prime} \mathrm{W}$ \\
\hline
\end{tabular}

\section{References}

Alves, T.M., Gawthorpe, R.L., Hunt, D.W., Monteiro, J.H., 2002. Jurassic tectonosedimentary evolution of the Northern Lusitanian Basin (offshore Portugal). Marine and Petroleum Geology 19, 727-754.

Aurell, M., Meléndez, G., Olóriz, F., (Coord.), Bádenas, B., Caracuel, J.E., García-Ramos, J.C., Goy, A., Iinares, A., Quesada, S., Robles, S., Rodríguez-Tovar, F.J., Rosales, I., Sandoval, J., Suárez de Centi, C. Tavera, J.M., Valenzuela, M., 2002. Jurassic. In: Gibbons, W., Moreno, M.T. (Eds.), The Geology of Spain. Geological Society, London, pp. 213-253.

Aurell, M., Robles, S., Badenas, B., Rosales, I., Quesada, S., Melendez, G., Garcia-Ramos, J.C. 2003. Transgressive-regressive cycles and Jurassic palaeogeography of northeast Iberia. Sedimentary Geology 162, 239-271.
Azañón, J.M., Galindo-Zaldivar, J., García-Dueñas, V., Jabaloy, A., 2002. Alpine tectonics II: Betic Cordillera and Balearic Islands. In: Gibbons, W., Moreno, M.T. (Eds.), The Geology of Spain. Geological Society, London, pp. 401-416.

Azerêdo, A.C., 1998. Geometry and facies dynamics of Middle Jurassic carbonate ramp sandbodies, West-Central Portugal. Geological Society, London, Special Publications $149,281-314$

Azerêdo, A., Duarte, L.V., Henriques, M.H., Manupella, G., 2003. Da dinâmica continental no Triásico aos Mares no Jurássico Inferior e Médio. Cadernos de Geologia de Portugal. Inst. Geol. Mineiro, Lisboa. 43 pp.

Brilha, J., Andrade, C., Azerêdo, A., Barriga, F.J.A.S., Cachão, M., Couto, H., Cunha, P.P., Crispim, J.A, Dantas, P., Duarte, L.V., Freitas, M.C., Granja, M.H., Henriques, M.H., Henriques, P., Lopes, L., Madeira, J., Matos, J.M.X., Noronha, F., Pais, J., Piçarra, J., Ramalho, M.M., Relvas, J.M.R.S., Ribeiro, A., Santos, A., Santos, V., Terrinha, P., 2005. Definition of the Portuguese frameworks with international relevance as an input for the European geological heritage characterization. Episodes 28, 177-186.

Cope, J.C.W., Inham, J.K., Rawson, P.F., 1992. Atlas of Palaeogeography and Lithofacies. Geological Society, London.

de Graciansky, P.C., Jacquin, T., 2003. Structural and palaeogeographical evolution of the Paris Basin during the Mid-Cimmerian events. Bulletin de la Societe Geologique de France 174, 3-17.

de Graciansky, P.C., Jacquin, T. Hesselbo, S.P., 1998. The Ligurian cycle: an overview of Lower Jurassic 2nd-order transgressive/regressive facies cycles in western Europe. In: Graciansky de, P.C. Hardenbol, J., Jacquin, T., Farley, M., Vail, P.R. (Eds.), Mesozoic-Cenozoic Sequence Stratigraphy of European Basins. Socie y of Economic Paleontologists and Mineralogists (SEPM). Society for Sedimentary Geology Special Publications, Tulsa, pp. 467-479. Special Publications No. 60.

Dewey, J.F., Helman, M.L., Knott, S.D., Turco, E., Hutton, D.H.W., 1989. Kinematics of the western Mediterranean. Geological Society, London, Special Publications 45, $265-283$.

Duarte, L.V., 1997. The marly-limestone deposition in the Toarcian-Lower Aalenian of the Lusitanian Basin (Portugal). Facies analysis and sedimentary evolution. Comunicaciones IV Congreso de Jurásico de España, Alcañiz (Teruel), pp. 67-68.

Duarte, L.V., Henriques, M.H., 2001. Les événements biosédimentaires du passage Lias/ Dogger au Portugal. Importance pour la connaissance géodynamique du secteur Nord Atlantique. Livre des Résumes du 16éme Colloque des Bassins Sédimentaires Marocains, pp. 28-29.

Duarte, L.V., Krautter, M., Soares, A.F., 2001. Bioconstructions a spongiaires siliceux dans le Lias terminal du Bassin lusitanien (Portugal); stratigraphie, sedimentologie et signification paleogeographique. Bulletin de la Societe Geologique de France 172, 637-646.

Dunham, R.J., 1962. Classification of carbonate rocks according to depositional texture. In: Ham, W.E. (Ed.), Classification of Carbonate Rocks. Memoir of the American Association of Petroleum Geologists 1, pp. 108-121.

El Hammichi, F., Elmi, S., Faure-Muret, A., Benshilil, K., 2002. Une plate-forme en distension, temoin de phases pre-accretion tethysienne en Afrique du Nord pendant le Toarcien-Aalenien (synclinal Iguer Awragh-Afennourir, Moyen Atlas occidental, Maroc)A pre-accretional extensional platform of the North African Tethys during the Toarcian-Aalenian (Iguer Awragh-Afennourir syncline, western Middle Atlas, Morocco). Comptes Rendus Geosciences 334, 1003-1010.

Fernández-López, S., Gómez, J.J., 1990. Evolution tectono-sédimentaire et genese des associations d'ammonites dans le secteur central du Bassin Ibérique (Espagne) pendant l'Aalenien. Cahiers de l'Université Catholique de Lyon, pp. 39-52.

Fernández-López, S., Gómez, J.J., Goy, A., 1985. Le Dogger de Caudiel.Sédimentologie des carbonates développés sur un "monticule" de matériaux volcaniques. Strata 2, 101-115.

Fernández-López, S., Goy, A., Ureta, M.S., 1988. El Toarciense superior, Aaleniense y Bajociense inferior en Camino (Santander). Precisiones bioestratigráficas. Ciencias de la Tierra, Geología, pp. 47-62.

Ford, D., Golonka, J., 2003. Phanerozoic paleogeography, paleoenvironment and lithofacies maps of the circum-Atlantic margins: paleogeographic reconstruction and hydrocarbon basins: Atlantic, Caribbean, South America, Middle East, Russian Far East, Arctic. Marine and Petroleum Geology 20, 249-285.

García-Frank, A., 2007. Evolución biosedimentaria y secuencial del Jurásico Medio inferior en la Cuenca Ibérica (Sector NO). PhD Thesis, Universidad Complutense de Madrid, Servicio de Publicaciones, [on line]. (Available at http://www.ucm.es/ BUCM/tesis/geo/ucm-t\%2029198.pdf) (Date accessed: [02.22.2007]).

García-Frank, A., Ureta, S., Mas, R., 2006a. Aalenian- Bajocian iron-coated grains: evolutionary stages, sequence distribution and genetic significance (Iberian Basin, Spain). Volumina Jurassica IV, 88-89.

García-Frank, A., Ureta, S., Mas, R., 2006b. Tectonically active Aalenian in the Northwestern Iberian Basin (Spain). Volumina Jurassica IV, 42.

Gautier, F., Odin, G.S., 1983. Volcanisme Jurassique du Sud de l'Aragon (Espagne). Compte Rendu Soc. Géol. France, vol. 2, pp. 73-77.

Geiger, M., Schweigert, G., 2006. Toarcian-Kimmeridgian depositional cycles of the south-western Morondava Basin along the continental margin of Madagascar. Facies 52, 85-112.

Geiger, M., Clark, D.N., Mette, W., 2004. Reappraisal of the timing of the breakup of Gondwana based on sedimentological and seismic evidence from the Morondava Basin, Madagascar. Journal of African Earth Sciences 38, 363-381.

Golonka, J., 2004. Plate tectonic evolution of the southern margin of Eurasia in the Mesozoic and Cenozoic: EUROPROBE, GeoRift 3: Intraplate Tectonics and Basin Dynamics. The Lithosphere of the Southern Eastern European Craton and its Margin. Tectonophysics 381, 235-273.

Golonka, J., 2007. Late Triassic and Early Jurassic palaeogeography of the world: Triassic-Jurassic Boundary events: problems, progress, possibilities. Palaeogeography, Palaeoclimatology, Palaeoecology 244, 297-307. 
Golonka, J., Krobiki, M., Pajak, J., Van Giang, N., Zuchiewicz, W., 2006. Global plate tectonics and palaeogeography of Southeast Asia. Faculty of Geology, Geophysics and Environmental Protection. AGH University of Science and Technology, Arkadia, Krakow, Poland.

Gómez, J.J., 1979. El Jurásico en facies carbonatadas del Sector Levantino de la Cordillera Ibérica. Seminarios de Estratigrafía. Serie Monografias, Universidad Complutense de Madrid. $683 \mathrm{pp}$.

Gómez, J.J., Fernández-López, S., 2004. Las unidades litoestratigráficas del Jurásico Medio de la Cordillera Ibérica. Geogaceta 35, 91-94

Gómez, J.J., Goy, A., 2005. Late Triassic and Early Jurassic palaeogeographic evolution and depositional cycles of the Western Tethys Iberian platform system (Eastern Spain). Palaeogeography, Palaeoclimatology, Palaeoecology 222, 77-94.

Gómez, J.J., Fernández-López, S.R., 2006. The Iberian Middle Jurassic carbonateplatform system: synthesis of the palaeogeographic elements of its eastern margin (Spain). Palaeogeography, Palaeoclimatology, Palaeoecology 236, 190-205.

Gómez, J.J., Comas-Rengifo, M.J., Goy, A., 2003. Las unidades litoestratigráficas del Jurásico Inferior de las cordilleras Ibérica y Costeras Catalanas. Revista de la Sociedad GeoloÂgica de España 16, 227-237.

Goy, A., Ureta, S., 1990. El Aaleniense en la Cordillera Ibérica. Cahiers Univ. Catho. Lyon, Sér. Sci., vol. 4, pp. 73-87.

Goy, A., Ureta, S., 1994. Bioestratigrafía del Aaleniense en el sector occidental de Cuenca Vasco-Cantábrica (España). Comunicaciones de las $\mathrm{X}$ Jornadas de Paleontología, Madrid, pp. 102-105.

Gradstein, F.M., Ogg, J.G., 2004. Geologic time scale 2004 - why, how, and where next! Lethaia 37, 175-181.

Guimerá, J., Mas, R, Alonso, A., 2004. Intraplate deformation in the NW Iberian Chain: Mesozoic extension and Tertiary contractional inversion. Journal of the Geological Society $161,291-303$.

Hallam, A., 2001. A review of the broad pattern of Jurassic sea-level changes and their possible causes in the light of current knowledge. Palaeogeography, Palaeoclimatology, Palaeoecology 167, 23-37.

Hallam, A., Sellwood, B.W., 1976. Middle Mesozoic sedimentation in relation to ectonics in the British area. The Journal of Geology 84, 301-321 Chicago.

Haq, B.U., Hardenbol, J., Vail, P.R, 1988. Mesozoic and Cenozoic chronostratigraphy and cycles of sea-level change. In: Wilgus, C.K., Hastings, B.S., Ross, C.A., Posamentier, H. Van Wagoner, J., Kendall, C.G.S.C. (Eds.), Sea-Level Changes - An Integrated Approach. Society of Economic Paleontologists and Mineralogists (SEPM). Society for Sedimentary Geology Special Publications, Tulsa, pp. 71-108. Special Publications No. 42.

Henriques, M.H., 1992. Biostratigrafia e Paleontología (Ammonoidea) do Aaleniano em Portugal (Sector Setentrional da Bacia Lusitaniana). PhD Thesis, Coimbra Univ. Portugal. $301 \mathrm{pp}$

Henriques, M.H., 1995. Les faunes d'ammonites de l'Aalénien portugais: Composition et implications paléobiogéographiques. Géobios. Mémoire Spécial 28, 229-235.

Henriques, M.H., 2000. Aalenian of the Zambujal de Alcaria Section (Central Lusitanian Basin, Portugal). GeoResearch Forum 6, 85-94

Henriques, M.H., Linares, A., Sandoval, J., Ureta, S., 1996. The Aalenian in the Iberia (Betic Lusitanian and Iberian Basins). GeoResearch Forum 1-2, 139-150.

Hesselbo, S.P., Jenkyns, H.C, 1998. British Lower Jurassic sequence stratigraphy. In: Graciansky de, P.C., Hardenbol, J., Jacquin, T., Vail, P.R. (Eds.), Mesozoic-Cenozoic Sequence Stratigraphy of European Basins. Society of Economic Paleontologists and Mineralogists (SEPM). Society for Sedimentary Geology Special Publications, Tulsa, pp. 561-581. Special Publications No. 60.

Jacquin, T., de Graciansky, P.C., 1998a. Major transgressive/regressive cycles: the stratigraphic signature of European basin development. In: de Graciansky, P.C. Hardenbol, J., Jacquin, T., Farley, M., Vail, P.R. (Eds.), Mesozoic and Cenozoic sequence stratigraphy of European basins. Society of Economic Paleontologists and Mineralogists (SEPM). Society for Sedimentary Geology Special Publications, Tulsa, pp. 15-29. Special Publications No. 60.

Jacquin, T., de Graciansky, P.C., 1998b. Transgressive/regressive (second-order) facies cycles: the effects of tectono-eustasy. In: de Graciansky, P.C., Hardenbol, J., Jacquin, T., Farley, M., Vail, P.R. (Eds.), Mesozoic and Cenozoic sequence stratigraphy of European basins. Society of Economic Paleontologists and Mineralogists (SEPM) Society for Sedimentary Geology Special Publications, Tulsa, pp. 31-42. Special Publications No. 60.

Jacquin, T., Dardeau, G., Durlet, C., Graciansky de, P.C., Hantzpergue, P., 1998. The North sea cycle: an overview of 2nd-order transgressive/regressive facies cycles in western Europe. In: Graciansky de, P.C., Hardenbol, J., Jacquin, T., Farley, M., Vail, P.R. (Eds.), Mesozoic and Cenozoic Sequence Stratigraphy of European Basins. Society of Economic Paleontologists and Mineralogists (SEPM). Society for Sedimentary Geology Special Publications, Tulsa, pp. 445-466. Special Publications No. 60.

Lago, M., (Coord.), Lago, M., Arranz, E., Gil, A., Pocovi, A., 2004. Magmatismo asociado. In: Vera, J.A. (Ed.), Geología de España. SGE-IGME, Madrid, pp. 522-525.

Lezin, C., Rey, J., Faure, P., Cubaynes, R., Pelissie, T., Durlet, C., Deconinck, J.-F., 2007 Tectono-biosedimentary recordings at the Lias-Dogger transition: example of the Quercy carbonate platform (Aquitaine Basin, France). Bulletin de la Societe Geologique de France 178, 275-291.

Manuppella, G., Marques, B., Rocha, R.B., 1988. Évolution tectono-sédimentaire du bassin de l'Algarve pendant le Jurassique. 2nd Int. Symposium on Jurassic Stratigraphy, Lisboa, pp. 1031-1046.

Martín-Algarra, A., Vera, J.A., (Coord.), Crespo-Blanc, A., Díaz de Federico, A., Estévez, A. López-Garrido, A.C., Molina, J.M., Morata, D., Puga, E., Sanz de Galdeano, C, 2004 Magmatismo, estructura y evolución tectónica de las Zonas Externas Béticas. In Vera, J.A. (Ed.), Geología de España. SGE-IGME, Madrid, pp. 385-389. magmatismo alcalino jurásico del sector SE de la Cadena Ibérica: composición y estructura. Geogaceta 20, 1687-1690.

Martínez González, R.M., Lago, M., Valenzuela Ríos, J.I., Vaquer, R., Salas, R., Dumitrescu, R., 1997. El volcanismo triásico y jurásico del sector SE de la Cadena Ibérica y su relación con los estadios de rift mesozoicos. Boletín Geológico y Minero 108, 367-376.

Mas, R, Benito, M.I., Arribas, J., Serrano, A., Guimerá, J., Alonso, A., Alonso-Azcárate, J., 2003. The Cameros Basin: from Late Jurassic-Early Cretaceous Extension to tertiary contractional inversion - implications of hydrocarbon exploration. Northwest Iberian Chain, North Spain. AAPG International Conference and Exhibition. Geol. Field Trip 11.

O'Dogherty, L., Sandoval, J., Vera, J.A., 2000. Ammonite faunal turnover tracing sea-level changes during the Jurassic (Betic Cordillera, Southern Spain). Journal of the Geological Society, London 157, 723-736.

Ortí, F., Vaquer, R., 1980. Volcanismo jurásico del sector valenciano de la Cordillera Ibérica. Distribución y trama estructural. Acta Geológica Hispánica XV, 127-130.

Pinheiro, L.M., Wilson, RC.L., Pena dos Reis, R., Whitmarsh, R.B., Ribeiro, A., 1996. The western Iberia margin: a geophysical and geological overview. In: Withmarsh, R.B., Sawyer, D.S., Klaus, D.S., Masson, D.G. (Eds.), Proceedings of the Ocean Drilling Program. Scientific Results, vol. 149, pp. 3-23.

Quesada, S., Robles, S., Rosales, I., 2005. Depositional architecture and transgressiveregressive cycles within Liassic backstepping carbonate ramps in the Basque Cantabrian basin, northern Spain. Journal of the Geological Society 162, 531-548.

Rasmussen, E.S., Lom holt, S., Andersen, C., Vejbaek, O.V., 1998. Aspects of the structural evolution of the Lusitanian Basin in Portugal and the shelf and slope area offshore Portugal. Tectonophysics 300, 199-225.

Razin, P., Bonijoly, D., Le Strat, P., Courel, L., Poli, E., Dromart, G., Elmi, S., 1996. Stratigraphic record of the structural evolution of the western extensional margin of the Subalpine Basin during the Triassic and Jurassic, Ardeche, France. Marine and Petroleum Geology 13, 625-652.

Rocha, R.B., Marques, B., 1981. Le Jurassique de L'Algarve (Portugal): Esquisse stratigraphique et évolution paléogéographique. Cuadernos de Geología, Universidad de Granada 10, 35-43.

Salas, R., Guimerá, J., Mas, R., Martín-Closas, C, Meléndez, A., Alonso, A., 2001. Evolution of the Mesozoic Central Iberian Rift System and its Cainozoic Inversion (Iberian Chain). In: Cavazza, W., Roberston, A.H.F.R., Ziegler, P. (Eds.), Peri-Tethyan Rift/ Wrench Basins and Passive Margins. Mém. Mus. Nat. Hist. Natur. 2001, pp. 145-185.

Sandoval, J., Henriques, M.H., Ureta, S., Goy, A., Rivas, P., 2001. The Lias/Dogger boundary in Iberia: Betic and Iberian Cordilleras and Lusitanian basin. Bulletin de la Société Geologique de France 172, 385-387.

Sandoval, J., O'Dogherty, L, Vera, J.A., Guex, J., 2002. Sea-level changes and ammonite faunal turnover during the Lias/Dogger transition in the western Tethys. Bulletin de la Société Geologique de France 173, 57-66.

Soares, A.F., Duarte, L.V., 1997. Tectonic an eustatic signatures in the Lower and Middle Jurassic of the Lusitanian Basin. Comunicaciones IV Congreso de Jurásico de España, Alcañiz (Teruel), pp. 111-114.

Terrinha, P., Ribeiro, C, Kullberg, J.C, Lopes, C, Rocha, R., Ribeiro, A, 2002. Compressive episodes and faunal isolation during rifting, Southwest Iberia. The Journal of Geology 110, 101-113.

Under hill, J.R., Partington, M.A., 1993. Jurassic thermal doming and deflation in the North Sea: implications of the sequence stratigraphic evidence. In: Parker, J.R. (Ed.), Petroleum Geology of Northwest Europe: Proceedings of the 4 th conference. The Geological Society of London, London, pp. 337-345.

Underhill, J.R., Partington, M.A., 1994. Use of Sequence Stratigraphy in defining and determining a regional tectonic control on the "Mid-Cimmerian Unconformity"Implications for North Sea basin development and the Global Sea Level Chart. In: Weimer, P., Posamentier, H. (Eds.), Siliciclastic sequence stratigraphy: recent developments and applications. American Association of Petroleum Geologists, Tulsa, Oklahoma, Memoir 58, pp. 449-484

Ureta, S., 1985. Bioestratigrafía y Paleontología (Ammonitina) del Aaleniense en el Sector Noroccidental de la Cordillera Ibérica. PhD Thesis, Departamento de Paleontología. Facultad de Ciencias Geológicas, Universidad Complutense de Madrid, Spain, $452 \mathrm{pp}$

Vail, P.R., Audemard, F., Bowman, S.A., Eisner, P.N., Perez-Cruz, C, 1991. The stratigraphic signature of tectonics, eustasy and sedimentology-an overview. In: Einsele, G., Ricken, W., Seilacher, A. (Eds.), Cycles and Events in Stratigraphy. Springer, Berlin, pp. 617-659.

Van Wagoner, J.C. Posamentier, H.W., Mitchum, R.W., Vail, P.R., Sarg, J.F., Loutit, T.S., Hardenbol, J., 1988. An overview of the fundamentals of sequence stratigraphy and key definitions. In: Wilgus, C.K., Hastings, B.S., Kendall, C.G.St.C., Posamentier, H.W., Ross, C.A. Van Wagoner, J.C. (Eds.), Sea-level changes - An Integrated Approach. Special Publication No. 42. Society of Economic Paleontologists and Mineralogists, Tulsa, pp. 39-45.

Wilson, R.C.L., 1988. Mesozoic development of the Lusitanian Basin, Portugal. Revista de la Sociedad Geológica de España 1, 393-407.

Wright, V.P., Wilson, R.C.L., 1984. A carbonate submarine-fan sequence from the Jurassic of Portugal. Journal of Sedimentary Petrology 54, 394-412.

Ziegler, P.A., 1990. Geological Atlas of Western and Central Europe. Shell Internationale Petroleum Maatschappij B. V., Mijdrecht.

Ziegler, P.A., 2004. Europe: Permian to recent evolution. In: Selley, R.C, Cocks, L.R., Plimer, I.R. (Eds.), The Encyclopedia of Geology. Elsevier, Amsterdam, pp. 102-125. 